\title{
The Neoproterozoic Pan-African basement from the Alpine Lower Danubian nappe system (South Carpathians, Romania)
}

\author{
J.P. Liégeois ${ }^{\mathrm{a},{ }^{*}}$, T. Berza ${ }^{\mathrm{b}}$, M. Tatu ${ }^{\mathrm{b}}$, J.C. Duchesne ${ }^{\mathrm{c}}$ \\ "Département de Géologie (Section de Géochronologie), Musée Royal de l'Afrique Centrale, B-3080 Tervuren, Belgium \\ ${ }^{b}$ Institutul Geologic al României. Str Caranbansebeş 1, Bucureşti 78344, Romania \\ 'Laboratoires Associés Géologie-Pérrologie-Géochimie, Universitê de Liège, Bat. 20, B-4000 Sart Tilman, Belgium
}

Received 27 March 1995; accepted 25 March 1996

\begin{abstract}
The South Carpathians, which were thrust to the Moesian platform in the Alpine orogeny (Late Cretaceous to Tertiary), include the Danubian nappe system. The Danubian pre-Alpine basement comprises two Variscan nappes, each one made up of partially retrogressed amphibolite facies rocks intruded by granitoids and capped by an Ordovician-Devonian volcano-sedimentary cover. No lithological correlation can be established between the pre-Ordovician basements of these two units.

The metamorphic basement from the first Variscan nappe, the Drăgşan Group, is composed of banded amphibolites with some augen and aluminous gneisses intruded by granodioritic to tonalitic plutons. The banded structure of the amphibolites, together with their geochemistry, suggests a volcano-sedimentary sequence. Zircon U-Pb data on an intercalated augen gneiss have given an age of $777 \pm 3 \mathrm{Ma}$ for the emplacement of the protolith of this gneiss. Nd model ages $\left(T_{\mathrm{DM}}\right)$ for the amphibolites range from $717 \mathrm{Ma}$ to $817 \mathrm{Ma}$. At $777 \mathrm{Ma}, \epsilon_{\mathrm{Nd}}$ values cluster is at +8.3 to +9.8 and $\mathrm{Sr}$ initial ratios range between 0.7007 and 0.7023 , indicating an oceanic origin without continental crust contamination. Major and trace elements from the Drăgşan amphibolites consistently display an island arc signature, with three differentiation trends evolving from an early tholeiitic trend to a more differentiated low-K calc-alkaline one. The Drăgşan terrane is similar to the early Pan-African juvenile terranes of the Sahara.

The basement of the second Variscan nappe, the Lainici-Păiuş Group, is made up of metasedimentary rocks (mainly quartzites, marbles and graphitic mica gneisses) cut by early leucogranitic dykes, medium-K calc-alkaline and alkali-calcic (mainly granitic) plutons, and late medium-K porphyry diorite dykes. This magmatism can be bracketed between $588 \mathrm{Ma}$ and $567 \mathrm{Ma}$ (U-Pb zircon ages). The best preserved pluton (Tismana, $567 \mathrm{Ma}$ old), displays a composite alkali-calcic (very high-K calc-alkaline) magmatic sequence, ranging from gabbro-diorite to monzogranite, including an ultramafic pod. Ages and geochemical signatures resemble the Saharan late Pan-African granitoids.

The existence of Late Precambrian partly juvenile terrains is thus confirmed within the basement of South Carpathians, which renders then a segment of the European Alpine belt that can be successfully compared to the Pan-African Trans-Saharan belt.
\end{abstract}

Keywords: Pan-African; Amphibolite; Island arc; Geochronology; Geochemistry; Romania

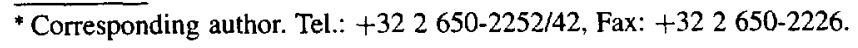




\section{Introduction}

Recent papers devoted to the basement of the Alpine belt in Europe have mentioned the possible existence of several Late Precambrian relics (Neubauer, 1991; Pin, 1991; von Raumer and Neubauer, 1993; Dallmeyer and Neubauer, 1994). Probably the largest of these relics is localized in the South Carpathians of Romania (Mînzatu et al., 1975; Grünenfelder et al., 1983; Kräutner et al., 1988; Kräutner, 1993; Berza et al., 1994). This paper confirms the existence of Late Precambrian lithologies in the South Carpathians and constrains their geodynamic palaeoenvironment. In the Alpine foreland of the Carpathians, contemporaneous terrains are only known in the Moravian zone northwest of the West Carpathians (Finger et al., 1989; Fig. 1). The foreland of the South Carpathians is of Mesoproterozoic age while that of the East Carpathians is Palaeoproterozoic. Correlations with the well-preserved PanAfrican belt of northern Africa in the Saharan Tuareg shield (Liégeois et al., 1994; Black et al., 1994) are suggested.

\section{The Danubian nappes: Alpine and Variscan features}

The $900 \mathrm{~km}$ long arcuate Carpathian mountain range in Romania comprises the East and South Carpathians. The Apuseni Mountains lie inside this Carpathian arc (Fig. 1). The East Carpathians are thrust upon the East European Palaeoproterozoic platform while the South Carpathians are thrust upon the Moesian Mesoproterozoic platform. The contact between these two platforms is NW-SE-oriented, passing below the bend of the Carpathian arc.

The South Carpathians were thrust upon the Moesian cratonic area in Upper Cretaceous to Tertiary times and, after erosion, have been partly covered by Oligocene to Neogene sediments. Current relief is due to intraplate deformation inside the Alpine framework, probably in response to horizcntal movements along roughly $\mathrm{E}-\mathrm{W}$-oriented shear zones. The small coal-bearing Oligocene-Miocene half-graben pull-apart basin of Petroşani is related to such a dextral movement along a major fault system (Berza and Drăgănescu, 1988; Ratschbacher et al., 1993;

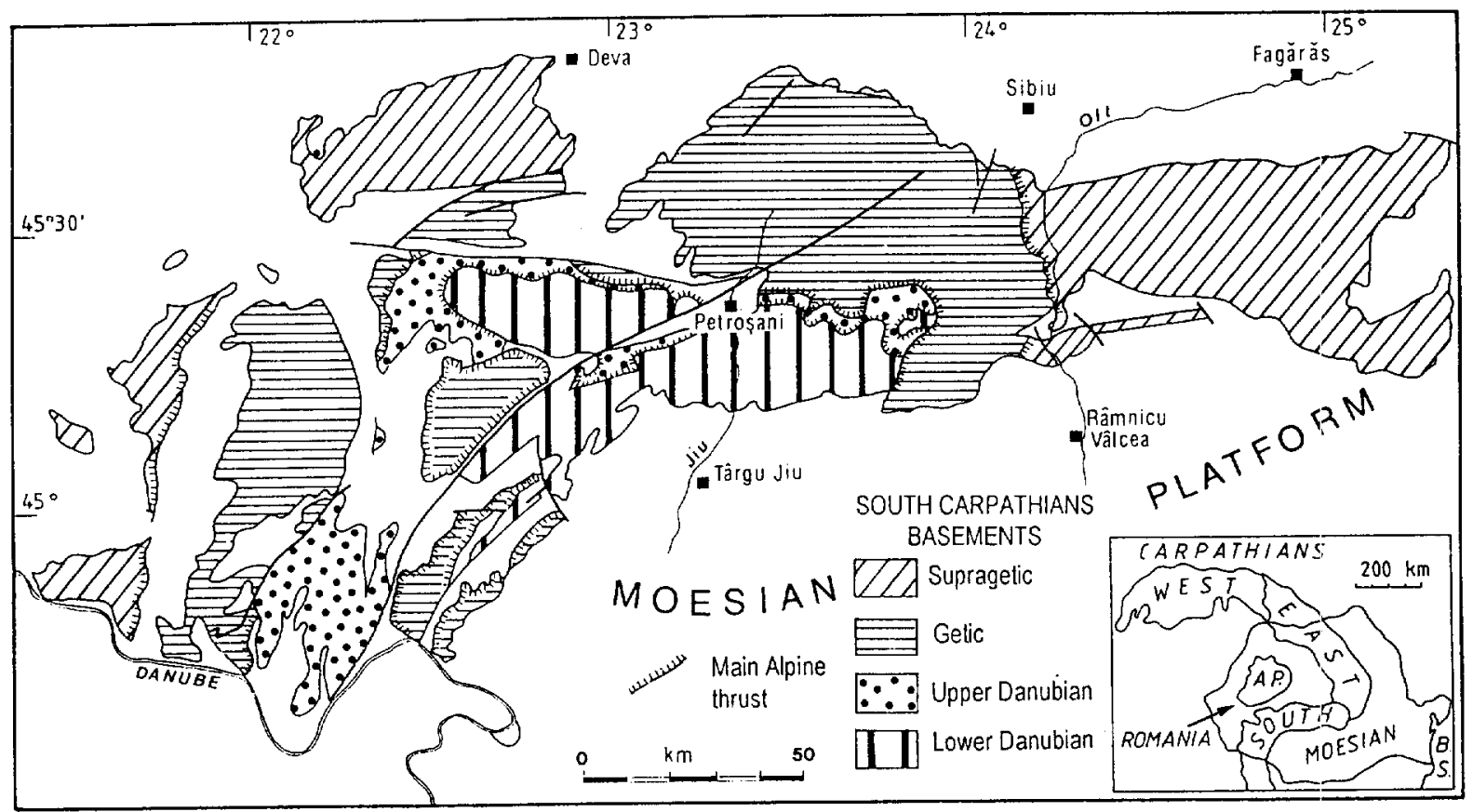

Fig. 1. The different Alpine thrust units in the South Carpathians (modified from Kräutner et al., 1988). Inset: main geographical subdivisions of the Carpathic arc and foreland in Romania (modified after Kräutner, 1988). A.P. = Apuseni Mountains; B.S. = Black Sea. 


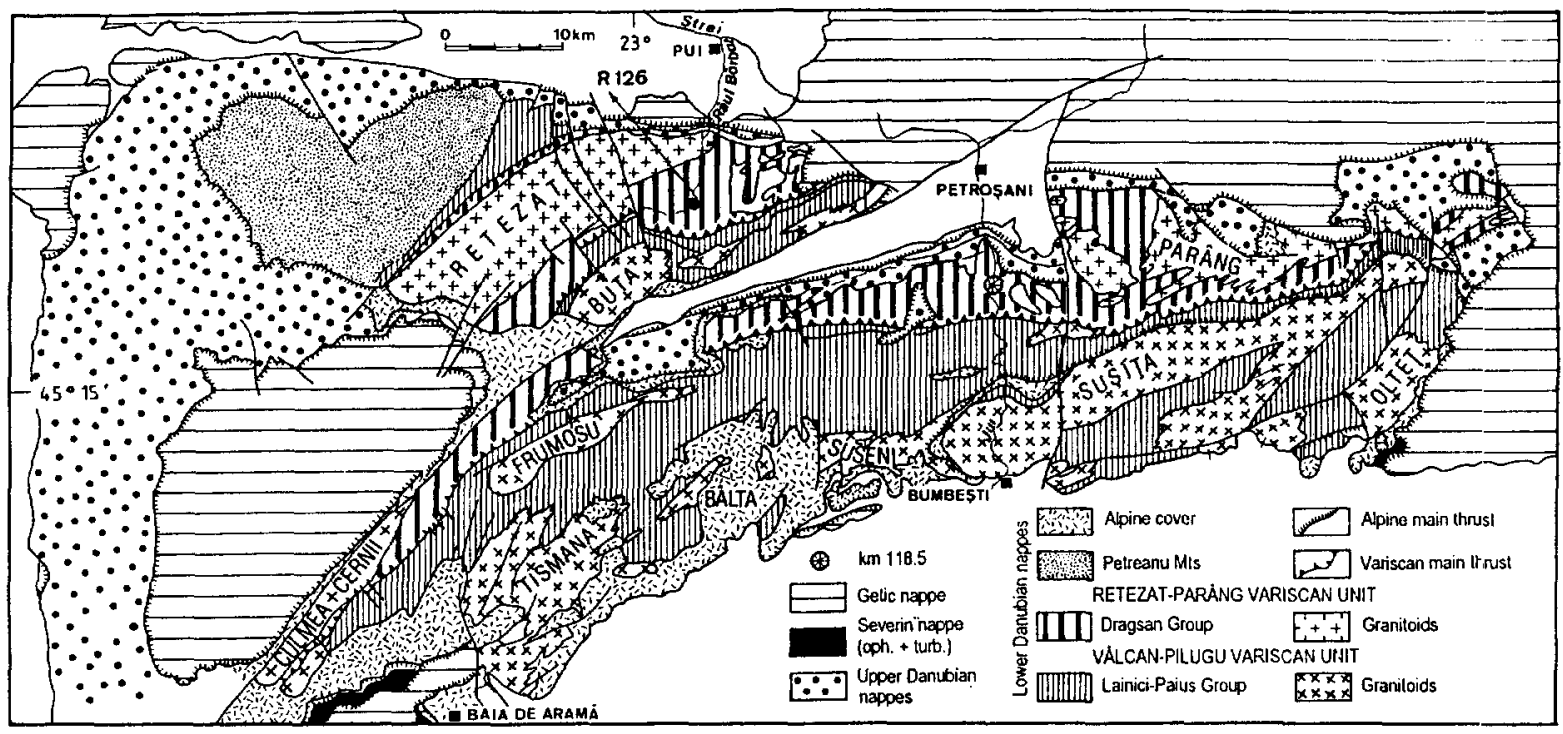

Fig. 2. Simplified geological map of the Danubian window in the South Carpathians (modified from Berza et al., 1994) enhancing the Precambrian lithologies. Km 118.5, south of Petroşani, represents the main sampling locus of Drăgşan metatuffs (groups A, B, C). Basement and Alpine cover of the Getic and Upper Danubian nappes have not been differentiated. As they are very limited in outcrop area, Ordovician to Carboniferous metasediments are not shown.

Berza et al., 1994). This recent tectonics has a brittle behaviour and its effects are limited to fault zones.

\subsection{The Alpine Danubian nappe system}

At the beginning of the century, Murgoci (1905) already recognized the Getic Nappe (Fig. 1) in the South Carpathians, thrust on a unit later termed Danubian by Codarcea (1940) and considered as autochthonous. The Supragetic Nappe (Fig. 1), resting upon the Getic Nappe (Streckeisen, 1934; Codarcea et al., 1967), and the ophiolite-bearing Severin Nappe (Codarcea, 1940), which is situated structurally between the Getic and Danubian nappes, have been recognized later. The Danubian was shown to constitute a nappe system (Berza et al., 1983; Fig. 2) representing the lowest part of the nappe pile in the South Carpathians. The assembly of the GeticSupragetic and Danubian terranes occurred only in the Upper Cretaceous. Before the collision, in Upper Jurassic-Lower Cretaceous, these terranes were separated by the Severin oceanic domain, implying that the pre-Alpine evolution of the Getic-Supragetic was drastically different from that of the Danubian.

The various Eoalpine (Cretaceous) Danubian nappes contain the same basement lithologies (Berza and Seghedi, 1983). They consist of several series metamorphosed in the amphibolite facies, and of a lot of late to post-kinematic granitoids (Fig. 2). They are capped by Mesozoic sediments, mainly carbonates, but locally also by fossiliferous Ordovician to Carboniferous sediments (Kräutner et al., 1981; Fig. 3). The Eoalpine thrusting induced mylonitisation and metamorphism within lower greenschist facies conditions on much of the Danubian rocks. However, unaffected or slightly affected domains can be found and their pre-Eoalpine evolution studied.

The Danubian nappe system has been subdivided in two parts, the Upper Danubian and the Lower Danubian (Berza et al., 1983, 1994; Figs. 1, 2), which are separated by a major thrust plane and differ in their Mesozoic covers (Stănoiu, 1973; Kräutner et al., 1981). In the Lower Danubian, two nappes have been distinguished: the Lainici and SchelaPetreanu nappes (Kräutner et al., 1981, 1988; Berza et al., 1994). This paper only deals with the basement of the Lower Danubian nappes. However, the basement of the Upper Danubian has similar lithologies (Berza and Seghedi, 1983; Kräutner et al., 1988; Kräutner, 1993; Berza et al., 1994). 

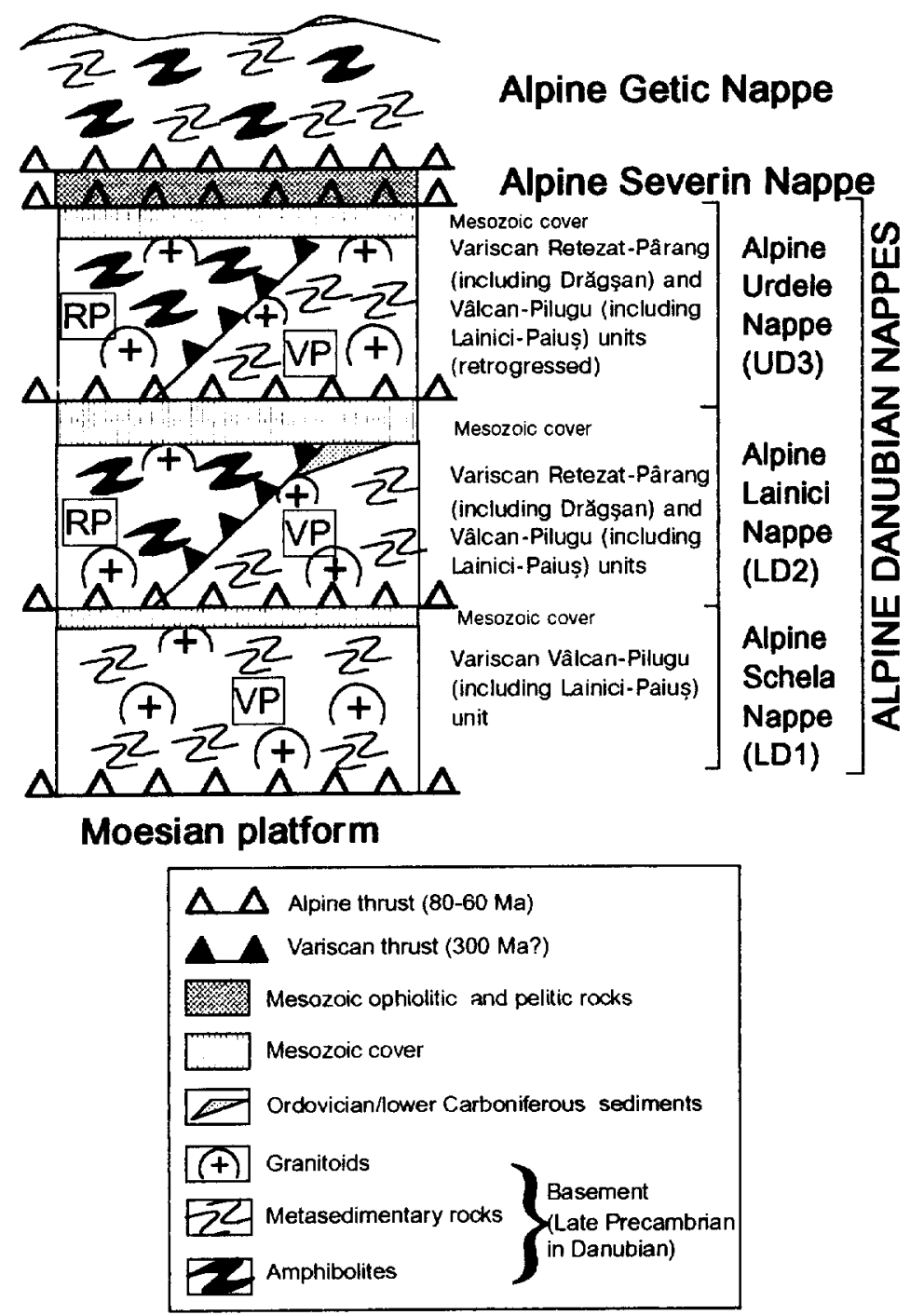

Fig. 3. Schematic cross-section of the Alpine Danubian nappe system in the studied area. The Variscan Retezat-Parâng nsıpe comprises the Drăgşan amphibolitic basement and the Retezat and Parâng types of granites. The Variscan Vâlcan-Pilugu nappe comprises the Lainici-Păiuş metasedimentary basement, the Lainici-Păiuş leucogranitoid dykes, the Suşiţa and Tismana pluton types and the Motru dyke swarms. Inside the Danubian, the Variscan thrusts separate different terranes (Drăgşan and Lainici-Păiuş Groups). This is not the case for the Alpine thrusts. $L D 1=$ Lower Danubian $1 ; L D 2=$ Lower Danubian 2; $U D 3=$ Upper Danubian 3. Upper Dariubian 1, 2 and 4 are only present more to the west. $V P=$ Vâlcan-Pilugu Variscan thrust unit; $R T=$ Retezat-Parâng Variscan thrust unit.

\subsection{The Variscan nappe system in the Lower Danubian}

The pre-Alpine thrusts in the Alpine Lower Danubian nappes are of Variscan age. Indeed, they have affected the Ordovician-Devonian sediments while the undeformed Permian sediments rest unconformably on the mylonites (Berza and Iancu, 1994).
Two Variscan thrust units have been defined (Figs. 2,3): the Vâlcan-Pilugu (VP) and the Retezat-Parâng (RP) units. The RP thrust unit rests always structurally upon the VP unit. Both Variscan thrust units are made of metamorphic rocks intruded by various granitoids and capped by Ordovician-Devonian seciments. The VP basement is metasedimentary (mainly quartzites and carbonates, the Lainici-Păiuş Group) while the 
RP basement is metavolcanic, mainly banded amphibolites, the Drăgşan Group.

The Variscan deformation and thrusting event resulted in the formation of 100 to $1000 \mathrm{~m}$ thick zone of greenschist facies mylonites. Variscan and Eoalpine dynamic effects cannot be easily distinguished. However, unlike the Eoalpine thrusts, the Variscan thrusts seem to separate different terranes (Kräutner, 1994). Even if $\mathrm{Ar}-\mathrm{Ar}$ ages give the most often Alpine or Variscan ages (Dallmeyer et al., 1994a,b), neither period of retrogression reached the amphibolite facies conditions, which can be identified only in rocks deformed during pre-Variscan events. This conclusion is confirmed by the preVariscan granitoids and the Palaeozoic sedimentary covers which, when they are affected by the Variscan thrusts, reequilibrated in greenschist facies conditions, but never to amphibolite facies.

\section{Precambrian lithologies in the Danubian basement}

\subsection{The Lainici-Păius metasedimentary group and its intrusives in the Vâlcan-Pilugu Variscan unit}

The Lainici-Păiuş Group (Manolescu, 1937) is composed of abundant quartzite, biotite gneiss, marble and graphitic gneiss, the richest parts of which are mined for graphite. Minor amphibolite is also present. Frequent migmatitic zones were formed during the pre-Ordovician regional upper amphibolite facies. Two formations have been distinguished (Berza, 1978; Schuster, 1980): (1) a 'Carbonate-Graphitic Formation', made up of crystalline limestone and dolomite, sillimanite-andalusite-cordierite-graphite-mica gneiss, amphibolite, calc-silicate gneiss and biotite gneiss; (2) a 'Quartzitic and Biotite Gneiss Formation', consisting of various quartzites interlayered with biotite \pm amphibole gneiss and minor amounts of amphibolite, marble and sillimanite gneiss. The Lainici-Păiuş Group is characteristically affected by low-pressure/hightemperature amphibolite facies metamorphism (Savu, 1970; Berza, 1978).

A characteristic feature of the Lainici-Păiuş Group is the abundance of leucogranitoid that intruded the metasediments as dykes or bodies (Berza, 1978). The bodies rarely exceed $100 \mathrm{~m}$. The dykes are often concordant, having intruded parallel to the metamorphic foliation after the peak of the amphibolite facies metamorphism. They can be considered as lit-parlit injections, or as late-metamorphic syn-kinematic dykes. These leucogranitoids, called Lainici-Păiuş leucogranitoid, correspond to $\sim 25 \%$ of the country rock. It is characterized by the common black colour of the porphyritic K-feldspar, scarce garnet, biotite and muscovite, and a heterogranular fabric. Some dykes are pegmatitic. Xenoliths from the country rocks are frequent in the dykes, though this feature can often be interpreted as blocks isolated by intrusion.

The Lainici-Păiuş metasediments and leucogranitic dykes were intruded by large elongated plutons of two types (Manolescu, 1937; Berza, 1978). The first one, the Suşiţa-type, is made up of medium$\mathrm{K}$ calc-alkaline granodiorite and tonalite (Savu et al., 1971). Mafic magmatic enclaves are abundant. The main plutons are Suşiţa, Frumosu, Olteţ and Buta (Fig. 2). They have been variably affected by Variscan and Eoalpine thrusts; Suşiţa is foliated, displaying $\mathrm{S}-\mathrm{C}$ mylonites, with only minor wellpreserved parts, while unaffected parts in the other plutons are common. The Tismana-type plutons display a composite alkali-calcic magmatic sequence (very high-K calc-alkaline, see below), ranging in composition from gabbro-diorite to syenogranite, including ultramafic pods (Berza, 1978). The mafic rocks are in general equigranular, pyroxene-bearing, and dominate at the margins of the plutons. The intermediate and acid rocks are commonly porphyritic and contain biotite and hornblende. Mafic microgranular enclaves are frequent and mingling/mixing processes between basic and acid magmas are conspicuous. Accumulation of K-feldspar is common. The two plutons of this group, Tismana and Novaci (Fig. 2), are weakly affected by later Variscan and Eoalpine thrusts.

The last pre-Ordovician magmatic manifestation is the intrusion of mainly porphyritic microdioritic or microgranodioritic and rare microgranitic or lamprophyric dykes from the Motru swarm (Berza and Seghedi, 1975) which, in contrast to the LainiciPăiuş leucogranitoidic dykes, crosscut the plutons. In the Frumosu pluton, these dykes contain granodioritic inclusions from the pluton with contorted and diffuse boundaries, suggesting that the Frumosu 
pluton was still hot when the Motru dykes were intruded.

\subsection{The Drăgşan metavolcanic group and its intrusives in the Retezat-Parâng Variscan unit}

The major part of the Drăgşan Group (Pavelescu, 1953 ) is composed of banded amphibolite, but also comprises ultramafic bodies, augen gneisses, biotite gneisses and rare marbles. It is affected by a Barrovian amphibolite facies metamorphism but many areas have been retrogressed to greenschist facies (Berza and Seghedi, 1983).

We interpret the banding of the amphibolites as an original pre-metamorphic feature which suggests a volcano-sedimentary origin (tuffs). Bodies of pyroxenites are known, especially in the Parâng Mountains (Micaia Mountain) where their lengths can reach 2-3 $\mathrm{km}$.

The Drăgşan Group was intruded by the Retezat, Parâng and Culmea Cernei plutons (Fig. 2). The Retezat pluton is leucocratic and composed of granodiorite and tonalite with some quartz diorite at its periphery. The Parâng and Culmea Cernei plutons are compositionally comparable to the Suşiţa type of the Vâlcan-Pilugu unit.

\section{Late Precambrian ages in the Danubian basement}

\subsection{Previous results}

In this paper, we will not discuss the numerous $\mathrm{K}-\mathrm{Ar}$ ages available for the Danubian basement (see Mînzatu et al., 1975; Grünenfelder et al., 1983; Kräutner et al., 1988), as this system has been strongly affected by both Variscan and Eoalpine thrusting events and often gives reset or partly reset ages. The oldest measured values (650-550 Ma) nevertheless gave rise to the suspicion of the existence of Precambrian terrains in the South Carpathians (Kräutner et al., 1988). Dallmeyer and Neubauer (1994) reported plateau ${ }^{40} \mathrm{Ar} /{ }^{39} \mathrm{Ar}$ ages between 600 and $300 \mathrm{Ma}$ for the Danubian basement, confirming the $\mathrm{K}-\mathrm{Ar}$ age range.

The only reliable and published Precambrian age for the Danubian is a zircon composite age for two different granites from the Vâlcan-Pilugu unit (Grü- nenfelder et al., 1983). Their data give an age of 582 $\pm 7 \mathrm{Ma}(2 \sigma)$ for a Lainici-Păiuş leucogranite from the Jiu valley, and of $588 \pm 5 \mathrm{Ma}(2 \sigma)$ for a granite from the Novaci pluton (recalculated from Grünenfelder et al., 1983). Both ages, upper intercepts of the discordias and based on four zircon fractions, are interpreted as the emplacement age. The lower intercepts are $-40 \pm 51 \mathrm{Ma}$ and $22 \pm 8 \mathrm{Ma}$, respectively, and probably correspond to continuous $\mathrm{Pb}$ loss. The negative lower intercept of the LainiciPăiuş leucogranite indicates that the emplacement age of this body is closer to $589 \mathrm{Ma}$ than to $575 \mathrm{Ma}$.

\subsection{New results}

Methods are described in the appendix and results are listed in Tables 1 and 2. Four zircon fractions from a granite sample of the Tismana pluton (Vâlcan-Pilugu unit, Fig. 4A; Table 1) determine a discordia line intercepting concordia at $567 \pm 3 \mathrm{Ma}$ ( $2 \sigma$, upper intercept $)$ and $19 \pm 8 \mathrm{Ma}(2 \sigma$, lower intercept). The absence of Variscan and Eoalpine events recorded in the zircon can be linked to the fact that the Tismana pluton is well preserved and only weakly affected by these events. As the post-nappe Alpine tectonics is only brittle and very localized, the lower intercept probably corresponds to a continuous $\mathrm{Pb}$ loss with no geological meaning. However, a Miocene Neoalpine effect cannot be ruled out. On the other hand, the upper intercept can orly date the intrusion of the pluton.

In the Retezat-Parâng unit, in the basin of the Râul Bărbat (Fig. 2), a kilometre-sized hody of augen gneiss, interfingered with amphibolites, was interpreted as a pre-metamorphic felsic pluton (Berza and Seghedi, 1983). Four zircon fractions from this augen gneiss (Fig. 4B; Table 1) determine a discordia line intercepting concordia at $777 \pm 3 \mathrm{Ma}(2 \sigma$, upper intercept) and $5 \pm 23 \mathrm{Ma}(2 \sigma$, lower intercept). Under the electron microscope, these zircons show no core, are well-zoned and display well-developed prisms with slightly rounded endings. They appear to be magmatic, with no or little metamorphic overprint. This is in agreement with the weak discordance of the analysed fractions. The upper intercept age (777 \pm 3 $\mathrm{Ma})$ is consequently interpreted as the irtrusion age of the protolith. The lower intercept corresponds to an Alpine effect or to continuous $\mathrm{Pb}$ loss. 

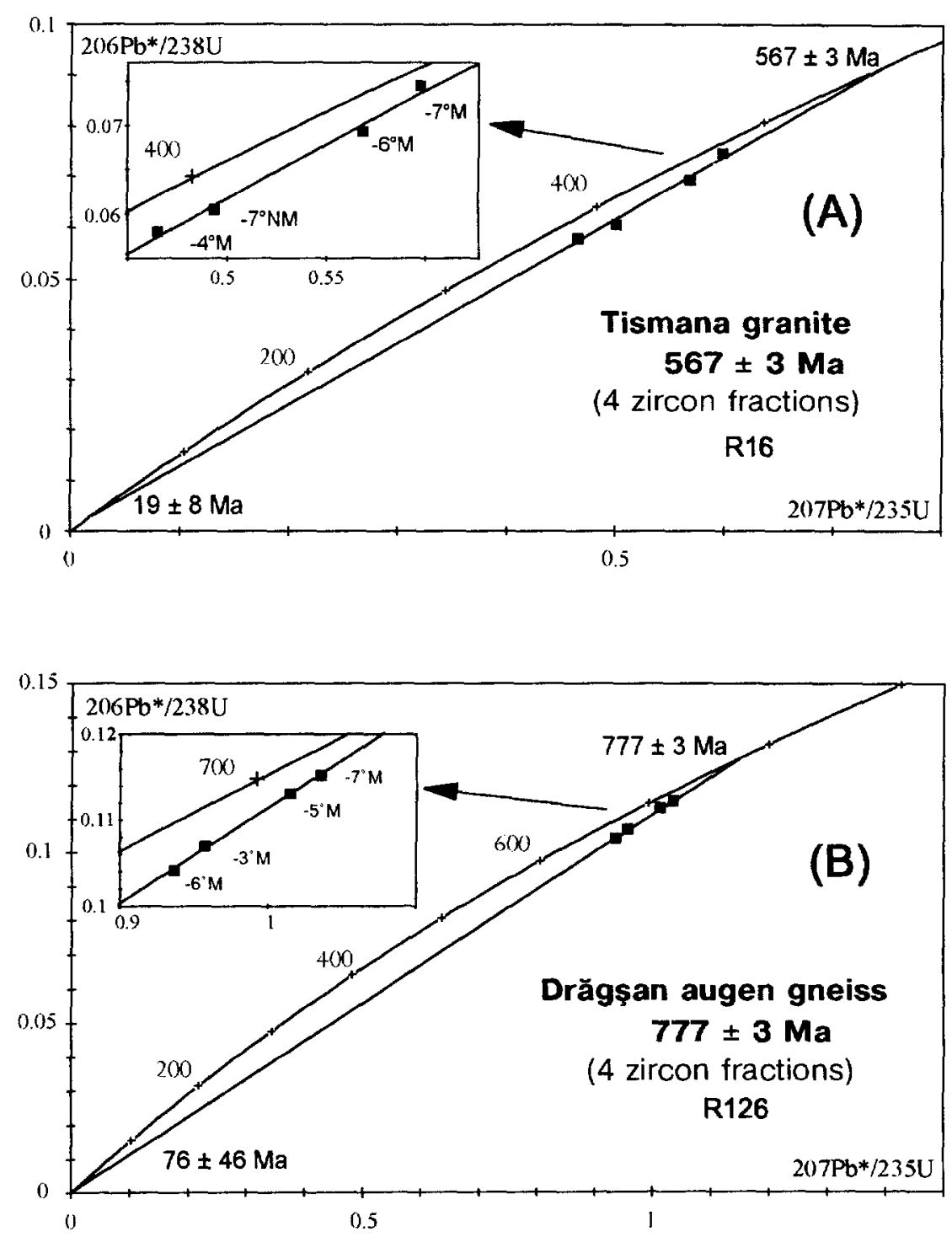

Fig. 4. (A) Zircon U-Pb Concordia diagram for the Drăgşan augen gneiss (Retezat-Parâng thrust unit). (B) Zircon U-Pb Concordia diagram for the Tismana pluton (Vâlcan-Pilugu thrust unit).

Sm-Nd isotopic measurements on Drăgşan banded amphibolites (samples preserved from Variscan and Alpine effects, collected along the Jiu Valley at $\mathrm{km}$ 118.5 on NR66) give an age for the protolith of 835 $\pm 200 \mathrm{Ma}(\mathrm{MSWD}=3.27,8 \mathrm{WR}$, Nd initial ratio $=0.51205 \pm 0.00004$ corresponding to $\epsilon_{\mathrm{Nd}}=+9.5$ \pm 1 ; Fig. 5A, Table 2). The zircon age of $777 \mathrm{Ma}$ of the augen gneiss is similar within errors. The MSWD value of 3.27 suggests that only small variations in the oceanic $\mathrm{Nd}$ initial ratio existed for the different amphibolite bands. The augen gneiss (R126) lies far below the amphibolites alignment indicating a different source $\left(\epsilon_{\mathrm{Nd}}\right.$ at $\left.777 \mathrm{Ma}=-5.4\right)$.

By contrast, $\mathrm{Rb}-\mathrm{Sr}$ isotopic measurements generate only an errorchron $(424 \pm 130 \mathrm{Ma}$; $\mathrm{Sr}$ initial ratio $=0.70276 \pm 0.00049 ; \mathrm{MSWD}=171 ;$ Fig. $5 \mathrm{~B}$, Table 2), which is obviously meaningless except that it corresponds to a value intermediate between 
Table 1

Zircon $\mathrm{U}-\mathrm{Pb}$ data

\begin{tabular}{|c|c|c|c|c|c|c|c|}
\hline & ${ }^{206} \mathrm{~Pb} /{ }^{204} \mathrm{~Pb}$ & ${ }^{207} \mathrm{~Pb} * \rho^{235} \mathrm{U}$ & ${ }^{206} \mathrm{~Pb}^{* / 238} \mathrm{U}$ & ${ }^{207} \mathrm{~Pb}^{*} /{ }^{206} \mathrm{~Pb}^{*}$ & $t\left({ }^{238} \mathrm{U}^{206} \mathrm{~Pb}^{*}\right)$ & $t\left({ }^{235} \mathrm{U}^{207} \mathrm{~Pb}^{*}\right)$ & $t\left({ }^{207} \mathrm{~Pb}^{*} /{ }^{206} \mathrm{~Pb}^{*}\right)$ \\
\hline \multicolumn{8}{|c|}{ Drăgşan augen gneiss (R126) } \\
\hline$-3^{\circ} \mathrm{M} / 63-106 \mu$ & $1379 \pm 2$ & 0.9568 & 0.1069 & 0.06489 & 655 & 682 & 771 \\
\hline$-5^{\circ} \mathrm{M} / 63-106 \mu$ & $1113 \pm 1$ & 1.0141 & 0.1131 & 0.06501 & 691 & 711 & 775 \\
\hline$-6^{\circ} \mathrm{M} / 63-106 \mu$ & $840 \pm 1$ & 0.93604 & 0.10417 & 0.06281 & 639 & 671 & 780 \\
\hline$-7^{\circ} \mathrm{M} / 63-106 \mu$ & $1614 \pm 1$ & 1.03494 & 0.11527 & 0.06512 & 703 & 722 & 779 \\
\hline \multicolumn{8}{|c|}{ Tismana granite (R16) } \\
\hline$-4^{\circ} \mathrm{M} / 100-150 \mu$ & $500 \pm 2$ & 0.4654 & 0.0579 & 0.05831 & 363 & 388 & 541 \\
\hline$-6^{\circ} \mathrm{M} / 100-150 \mu$ & $1054 \pm 5$ & 0.5684 & 0.0692 & 0.05953 & 432 & 457 & 587 \\
\hline$-7^{\circ} \mathrm{M} / 100-150 \mu$ & $2402 \pm 12$ & 0.5982 & 0.0745 & 0.05827 & 463 & 476 & 540 \\
\hline$-7^{\circ} \mathrm{NM} / 100-150 \mu$ & $1540 \pm 13$ & 0.4934 & 0.0605 & 0.05912 & 379 & 407 & 572 \\
\hline
\end{tabular}

Sample fractions are characterized by their diamagnetism and their granulometry: each fraction contains 4 to 6 grains. U/Pb and $\mathrm{Pb} / \mathrm{Pb}$ ages are expressed in Ma. Radiogenic lead ( $\left.\mathrm{Pb}^{*}\right)$ corrected for both blank (20-50 pg) and common lead (after the model of Stacey and Kramers, 1975).

the magmatic age and that of a major perturbation (Variscan thrusting?).

The $777 \pm 3 \mathrm{Ma}$ intrusive age for the augen gneiss is a minimum age for the amphibolite protolith. However, as the $T_{\mathrm{DM}}$ model ages of the latter ( 8 rocks; Table 2 ) range between $617 \pm 95 \mathrm{Ma}$ and $817 \pm 90 \mathrm{Ma}$ following the parameters of Golstein et al. (1984) or even younger following the parameters of Nelson and De Paolo (1985) or Michard et al. (1985), they cannot then be much older. The young $T_{\mathrm{DM}}$ values found with the two last sets of parameters point out the overall imprecision of the $T_{\mathrm{DM}}$ model ages which give ages with a precision, at best, of $\pm 100 \mathrm{Ma}$. At $777 \mathrm{Ma}$, the $\epsilon_{\mathrm{Nd}}$ of the individual amphibolite samples are bracketed between +8.2 and +9.8 , indicating a strong oceanic affinity (Fig. 10B). The present ${ }^{87} \mathrm{Sr} /{ }^{86} \mathrm{Sr}$ ratios are between 0.7037 and 0.7057 , and calculated back to $777 \mathrm{Ma}$ they are in the range $0.7007-0.7023$ (Table 2), also pointing to a depleted mantle origin. $\mathrm{The} \mathrm{Sr}_{\mathrm{i}}$ of the augen gneiss at $777 \mathrm{Ma}$ is 0.7045 , in agreement with the $\epsilon_{\mathrm{Nd}}$ of -5.4 , indicating a crustal component in the protolith.

\subsection{Interpretation}

In the Vâlcan-Pilugu unit, the three granitoids dated using U-Pb on zircon (Grünenfelder et al., 1983; this study) are in the same age range: $582 \pm$ $7 \mathrm{Ma}$ for the Lainici-Păiuş leucogranite, $588 \pm 5$ $\mathrm{Ma}$ for the Novaci pluton and $567 \pm 3 \mathrm{Ma}$ for the
Tismana pluton. This indicates that the late-kinematic Tismana-type plutons are not much younger than the syn-kinematic Lainici-Păiuş leucogranitoid that they intruded. As Suşiţa-type plutons are similar preVariscan elongated bodies as Tismana or Novaci and also crosscut the Lainici-Păiuş leucogranitoid, they can also be considered to have intruded within the same age range. If the field observations indicating than the Motru dyke swarm cut a still hot Frumosu pluton (Suşiţa type) are correct, this suggests that synto late-kinematic granitoids intrusive into the LainiciPăiuş metasediments were all emplaced in the 588$567 \mathrm{Ma}$ age range.

In the foreland of the Western Carpathians (Fig. 1), Cadomian granitic plutons within a 690$550 \mathrm{Ma}$ age range occur in the Moravian zone (Finger et al., 1989 and references therein) and similar ages have been obtained on the Lusatian granitoids in the northern Bohemian massif ( $542 \pm 9 \mathrm{Ma}$ and $587 \pm 17 \mathrm{Ma}, \mathrm{U}-\mathrm{Pb}$ on zircon, $573 \pm 44 \mathrm{Ma}, \mathrm{Rb}-$ Sr; Kröner et al., 1994) and on detrital muscovites from the Eastern Alps (Dallmeyer and Neubauer, 1994). This is also an age range typical for the latekinematic high-K calc-alkaline granitoids from the Pan-African belt of Saharan Africa (Liégeois et al., 1987, 1994; Schandelmeier et al., 1990). Moreover, as the Lainici-Păiuş leucogranitoids are concordant with the metamorphic foliation, the HT-LP amphibolite facies metamorphism that has affected the Lainici-Păiuş Group is probably not much older than $600 \mathrm{Ma}$, i.e. typically late Pan-African in age. 


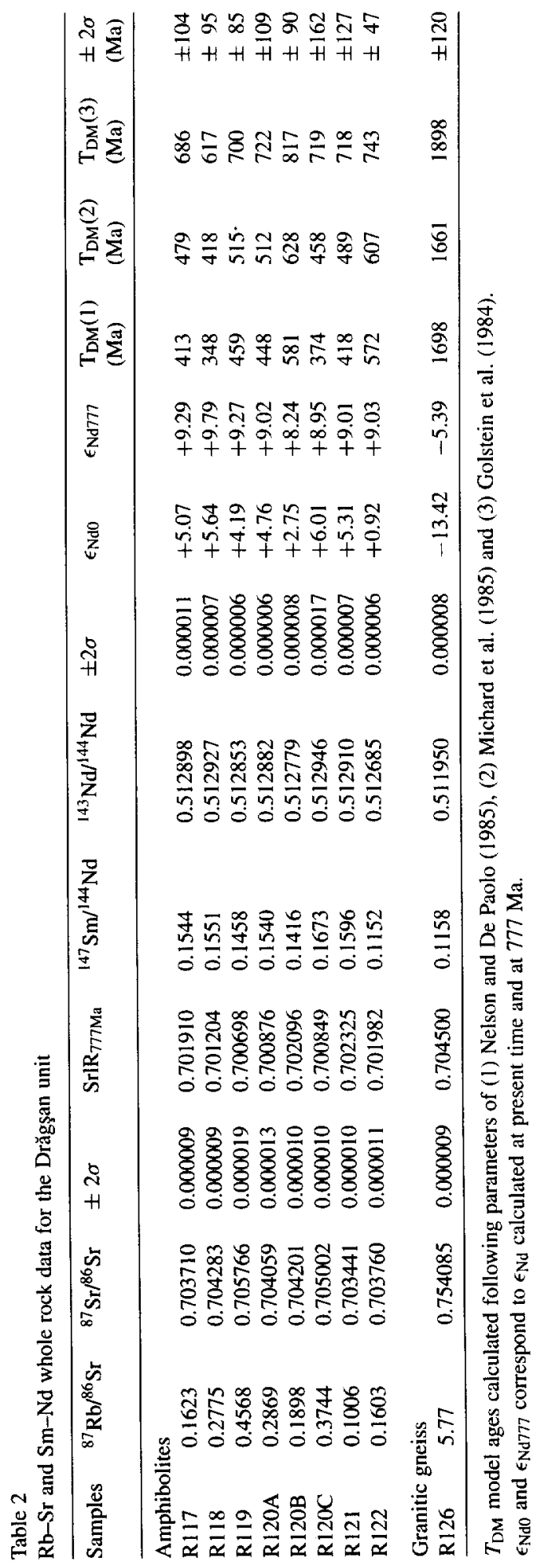



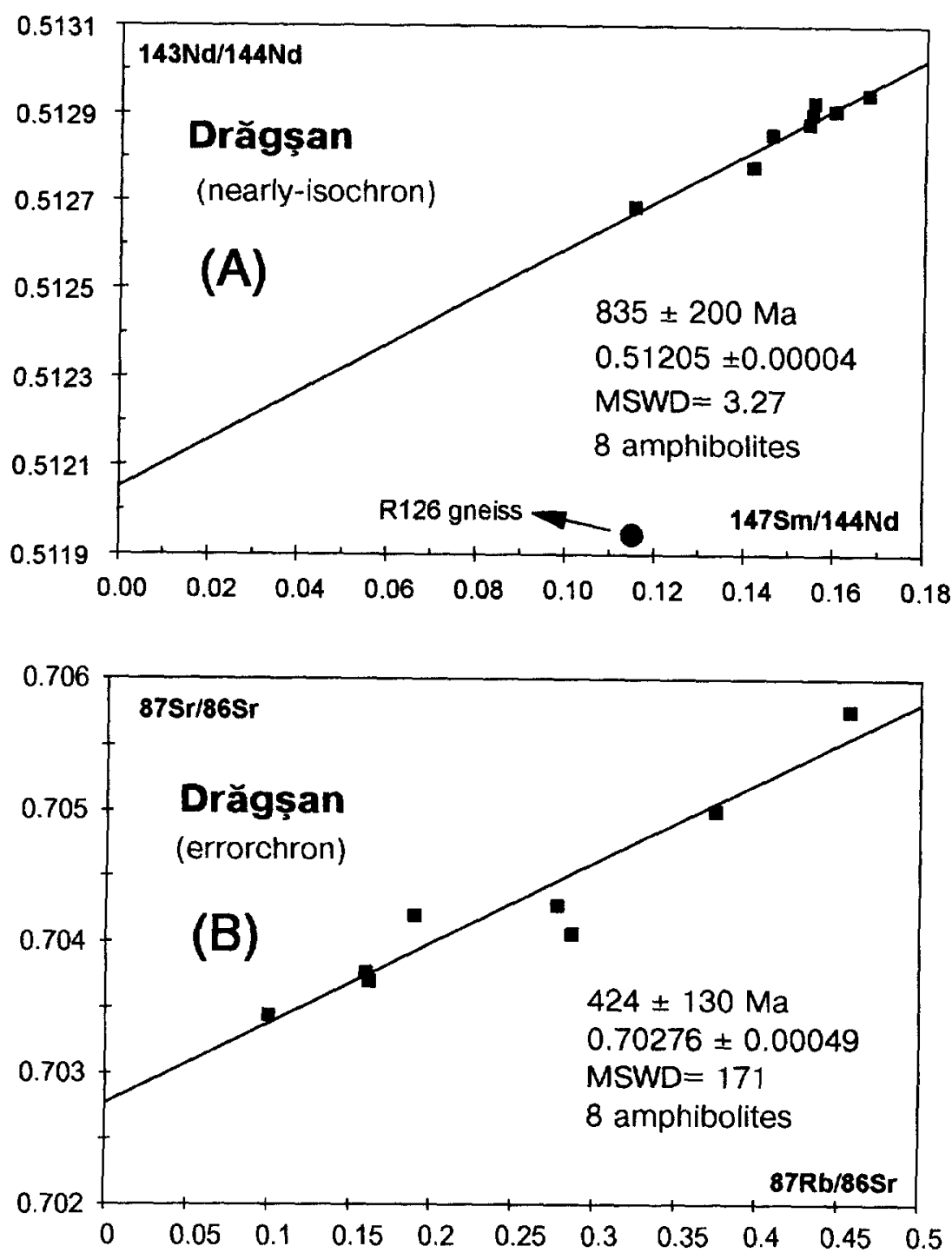

Fig. 5. (A) Sm-Nd (nearly) isochron from the Drăgşan banded amphibolites. The R126 augen gneiss lies well below this isochron. (B) $\mathrm{Rb}-\mathrm{Sr}$ errorchron from the Drăgşan banded amphibolites. This errorchron corresponds probably to a partial resetting of the Rb-Sr system during the Variscan thrusting.

In the Retezat-Parâng Variscan unit, the intrusion of the Drăgşan augen gneiss protolith has been dated at $777 \pm 3 \mathrm{Ma}$. This constitutes a minimum age for the banded amphibolites which cannot be much older (maximum $T_{\mathrm{DM}}$ model ages around $800 \mathrm{Ma}$ ). The $\mathrm{Sm}-\mathrm{Nd}$ isochron age of the amphibolites confirms this view $(835 \pm 200 \mathrm{Ma})$. These ages constitute a maximum value for the post-metamorphic intrusion of the Retezat, Parâng and Culmea Cernei granites.

$\mathrm{Sm}-\mathrm{Nd}$ isochron ages of $1018 \pm 59 \mathrm{Ma}$ for pla- gioclase amphibolites and $1071 \pm 43 \mathrm{Mla}$ for banded amphibolites from the Simplon area in the Alps have been reported by Stille and Tatsumoto (1985). The $777 \pm 3 \mathrm{Ma}$ age of the Drăgşan granite is comparable to the age of the early Pan-African events described in the Tuareg shield (Sahara: Black et al., 1994): to the west, the Tilemsi oceanic arc has been dated at $\sim 730 \mathrm{Ma}$ (Caby et al., 1989): ages around $850 \mathrm{Ma}$ have been obtained from the Iskel terrane (Caby et al., 1982) and around $730 \mathrm{Ma}$ in the juve- 


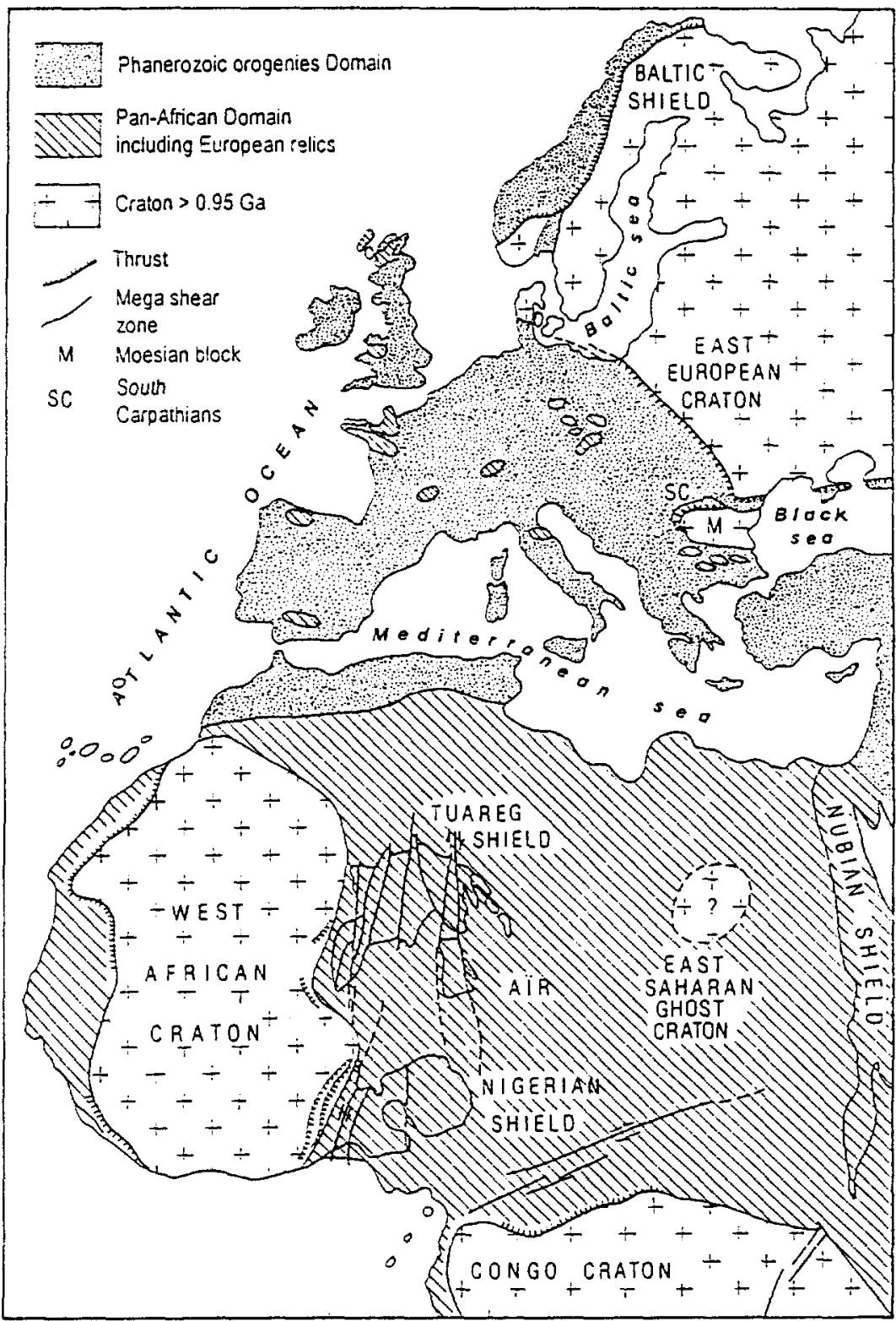

Fig. 6. Schematic map of northern Africa and Europe showing old cratons or platforms ( $>0.95 \mathrm{Ga}$ ), Neoproterozoic Pan-African domain and Phanerozoic orogeny domain (after Black and Liégeois, 1993; Choubert et al., 1984; Dallmeyer and Neubauer, 1994). This map shows the relative importance of the Neoproterozoic orogeny domain in northern Africa and Europe that justifies the use of the term Pan-African in Europe. A world-wide use of the term Pan-African is suggested for all the Neoproterozoic orogenies (800-540 Ma).

nile Aouzegueur terrane (Caby and AndreopoulosRenaud, 1987). The early high-pressure metamorphism described in Aïr (Nigerian Sahara) is just older than $730 \mathrm{Ma}$ (Liégeois et al., 1994). The two Cadomian or Baikalian age sets found in the
Danubian nappes ( $\sim 780 \mathrm{Ma}$ and $\sim 580 \mathrm{Ma})$ could correspond to the two coupled Pan-African orogenies of the Tuareg shield (Liégeois et al., 1994; Black et al., 1994). As the Pan-African orogeny is widely present in Africa (Fig. 6) where it is the 
Table 3

Chemical compositions of the Drăgşan unit

\begin{tabular}{|c|c|c|c|c|c|c|c|c|c|c|c|c|c|c|c|c|}
\hline & $\begin{array}{l}\text { Al } \\
\text { (R118) }\end{array}$ & $\begin{array}{l}\mathrm{A} 2 \\
\text { (R120A) }\end{array}$ & $\begin{array}{l}\mathrm{A} 3 \\
(\mathrm{R} 206 \mathrm{~B}) \\
\end{array}$ & $\begin{array}{l}\mathrm{Bl} \\
\text { (R120C) }\end{array}$ & $\begin{array}{l}\text { B2 } \\
\text { (R117) } \\
\end{array}$ & $\begin{array}{l}\text { B3 } \\
\text { (R119) }\end{array}$ & $\begin{array}{l}\text { B4 } \\
\text { (R121) } \\
\end{array}$ & $\begin{array}{l}\text { B5 } \\
\text { (R208) } \\
\end{array}$ & $\begin{array}{l}\text { B6 } \\
\text { (R207) } \\
\end{array}$ & $\begin{array}{l}\text { Cl } \\
\text { (R209) } \\
\end{array}$ & $\begin{array}{l}\mathrm{C} 2 \\
\text { (R120B) }\end{array}$ & $\begin{array}{l}\text { C3 } \\
\text { (R206A) }\end{array}$ & $\begin{array}{l}\text { C4 } \\
\text { (R122) } \\
\end{array}$ & $\begin{array}{l}\text { M1 } \\
\text { (R244) } \\
\end{array}$ & $\begin{array}{l}\text { M2 } \\
\text { (R245) } \\
\end{array}$ & $\begin{array}{l}A G \\
(R 126) \\
\end{array}$ \\
\hline $\mathrm{SiO}_{2}$ & 51.14 & 48.96 & 48.04 & 47.24 & 47.57 & 49.10 & 53.64 & 50.48 & 49.99 & 62.54 & 61.51 & 63.87 & 66.60 & 50.31 & 49.43 & 67.67 \\
\hline $\mathrm{TiO}_{2}$ & 2.65 & 2.73 & 2.76 & 1.50 & 1.75 & 1.80 & 1.52 & 1.34 & 1.54 & 0.80 & 0.89 & 0.62 & 0.31 & 0.13 & 0.05 & 0.64 \\
\hline $\mathrm{Al}_{2} \mathrm{O}_{3}$ & 13.82 & 14.48 & 13.77 & 16.09 & 16.18 & 16.89 & 17.17 & 16.95 & 16.86 & 16.13 & 17.05 & 15.62 & 17.55 & 4.16 & 3.76 & 14.34 \\
\hline $\mathrm{Fe}_{2} \mathrm{O}_{3}$ & 5.30 & 5.87 & n.d. & 4.13 & 3.96 & 3.49 & 4.25 & n.d. & n.d. & n.d. & 2.75 & n.d. & 1.77 & n.d. & n.d. & 1.22 \\
\hline $\mathrm{FeO}$ & 8.09 & 7.83 & n.d. & 7.07 & 7.49 & 7.07 & 5.42 & n.d. & n.d. & n.d. & 3.76 & n.d. & 1.02 & n.d. & n.d. & 3.85 \\
\hline $\mathrm{MnO}$ & 0.25 & 0.25 & 0.30 & 0.16 & 0.18 & 0.22 & 0.20 & 0.24 & 0.24 & 0.09 & 0.09 & 0.11 & 0.07 & 0.15 & 0.14 & 0.05 \\
\hline $\mathrm{MgO}$ & 4.32 & 5.27 & 7.07 & 8.42 & 6.87 & 6.27 & 3.97 & 5.31 & 5.56 & 2.88 & 2.60 & 3.40 & 0.87 & 20.16 & 20.15 & 1.7 \\
\hline $\mathrm{CaO}$ & 7.73 & 8.15 & 8.76 & 7.82 & 9.03 & 7.42 & 6.99 & 7.77 & 7.67 & 3.02 & 3.51 & 4.47 & 3.65 & 15.60 & 17.52 & 0.94 \\
\hline $\mathrm{Na}_{2} \mathrm{O}$ & 2.24 & 1.81 & 2.46 & 2.62 & 2.89 & 2.15 & 3.56 & 3.33 & 2.66 & 3.29 & 3.95 & 4.56 & 4.69 & 0.34 & 0.12 & 2.24 \\
\hline $\mathrm{K}_{2} \mathrm{O}$ & 0.85 & 1.09 & 0.74 & 1.03 & 0.57 & 1.22 & 0.59 & 0.80 & 0.84 & 2.00 & 1.07 & 0.76 & 1.14 & 0.07 & 0.03 & 4.15 \\
\hline $\mathrm{P}_{2} \mathrm{O}_{5}$ & 0.37 & 0.47 & 0.41 & 0.26 & 0.26 & 0.37 & 0.33 & 0.25 & 0.31 & 0.13 & 0.15 & 0.15 & 0.14 & 0.02 & 0.01 & 0.11 \\
\hline $\mathrm{PF}$ & 2.32 & 2.18 & 1.31 & 2.97 & 2.58 & 3.03 & 2.20 & 1.32 & 1.55 & 2.21 & 2.55 & 1.13 & 1.46 & 1.06 & 1.58 & 2.54 \\
\hline Total & 99.97 & 99.95 & 99.90 & 100.09 & 100.16 & 99.81 & 100.43 & 99.44 & 99.33 & 100.09 & 100.29 & 100.86 & 99.39 & 99.19 & 99.07 & 99.87 \\
\hline $\mathrm{Fe}_{2} \mathrm{O}_{3 \mathrm{t}}$ & 14.28 & 14.56 & 14.28 & 11.98 & 12.28 & 11.34 & 10.26 & 11.65 & 12.11 & 7.00 & 6.92 & 6.17 & 2.91 & 7.19 & 6.28 & 5.49 \\
\hline $\mathrm{V}$ & 399 & 429 & 465 & 273 & 349 & 282 & 213 & 293 & 308 & 138 & 141 & 97 & 45 & 207 & 211 & 53 \\
\hline $\mathrm{Rb}$ & $20.3^{*}$ & $22.1 *$ & $17.2^{*}$ & $20.8 *$ & $14.1^{*}$ & $29.4^{*}$ & $12.5^{*}$ & $15.3^{*}$ & $18.0^{*}$ & 42.4 & $22.4^{*}$ & $16.0^{*}$ & $22.1 *$ & $0.2 *$ & $0.2 *$ & 172.3 \\
\hline$Y$ & 45.4 & 44.3 & 36.1 & 26.1 & 27.1 & 27.0 & 31.0 & 27.2 & 35.6 & 31.8 & 26.2 & 21.6 & 13.3 & 3.9 & 1.2 & 40.97 \\
\hline $\mathrm{Zr}$ & 188 & 193 & 179 & 83 & 110 & 121 & 99 & 116 & 69 & 181 & 184 & 120 & 148 & 2.2 & 0.4 & 308.02 \\
\hline $\mathrm{Nb}$ & 7.8 & 9.2 & 7.9 & 3.5 & 4.9 & 5.6 & 3.8 & 2.2 & 2.5 & 5.8 & 5.4 & 3.4 & 2.8 & 0.1 & 0.1 & 21.1 \\
\hline $\mathrm{Ba}$ & 163 & 179 & 155 & 185 & 102 & 205 & 165 & 260 & 200 & 366 & 206 & 234 & 310 & 5.22 & 3.62 & 572.93 \\
\hline $\mathrm{La}$ & & 14.7 & 14.3 & 6.1 & 8.4 & 10.7 & 10.4 & 9.6 & 8.3 & 20.6 & 15.8 & 11.0 & 13.6 & 0.5 & 0.2 & 60.7 \\
\hline $\mathrm{Ce}$ & 40.1 & 42.8 & 40.3 & 18.7 & 24.2 & 29.9 & 27.4 & 27.3 & 26.1 & 52.6 & 40.7 & 30.2 & 32.3 & 1.9 & 0.6 & 129.4 \\
\hline $\operatorname{Pr}$ & 5.76 & 6.15 & 5.85 & & 3.57 & 4.33 & 3.98 & 3.85 & 4.10 & 6.93 & 5.27 & 4.07 & 3.94 & 0.31 & 0.07 & 14.32 \\
\hline Nd & 28.4 & 30.0 & 29.0 & 14.9 & 17.2 & 20.3 & 19.6 & 18.9 & 21.6 & 30.4 & 23.6 & 18.5 & 15.6 & 1.9 & 0.6 & 52.6 \\
\hline $\mathrm{Sm}$ & 7.28 & 7.65 & 7.51 & 4.12 & 4.39 & 4.90 & 5.18 & 4.90 & 6.11 & 6.84 & 5.54 & 4.15 & 2.97 & 0.63 & 0.19 & 10.07 \\
\hline $\mathrm{Eu}$ & 42 & 2.69 & 2.69 & 1.47 & 1.67 & 1.83 & 1.78 & 1.79 & 2.07 & 1.72 & 1.54 & 1.48 & 1.02 & 0.18 & 0.03 & 1.29 \\
\hline $\mathrm{Gd}$ & 8.19 & 8.63 & 5.97 & 4.69 & 5.06 & 5.37 & 5.67 & 4.06 & 5.20 & 5.19 & 5.70 & 3.16 & 2.85 & 0.61 & 0.12 & 9.72 \\
\hline Dy & 60 & 7.64 & 7.94 & 4.44 & 4.56 & 4.63 & 5.4 & 5.85 & 7.46 & 6.75 & 4.91 & 4.49 & 2.27 & 1.02 & 0.46 & 8.24 \\
\hline Ho & 1.61 & 1.60 & 1.54 & 0.96 & 0.93 & 0.93 & 1.12 & 1.16 & 1.50 & 1.28 & 1.00 & 0.87 & 0.47 & 0.19 & 0.06 & 1.57 \\
\hline $\mathrm{Er}$ & 29 & 4.26 & 4.35 & 2.40 & 2.55 & 2.56 & 3.17 & 3.39 & 4.34 & 3.86 & 2.75 & 2.62 & 1.46 & 0.59 & 0.27 & 4.42 \\
\hline $\mathrm{Yb}$ & & 3.90 & 3.87 & 2.38 & 2.25 & 2.15 & 3.00 & 3.32 & 3.92 & 3.71 & 2.88 & $2.7 !$ & 1.62 & 0.52 & 0.24 & 4.17 \\
\hline $\mathrm{Lu}$ & & 0.56 & 0.54 & 0.30 & 0.32 & 0.30 & 0.42 & 0.46 & 0.52 & 0.51 & 0.43 & 0.37 & 0.27 & 0.06 & 0.04 & 0.60 \\
\hline $\mathrm{Hf}$ & 4. & 4.54 & 5.1 & 2.17 & 2.54 & 2.76 & 2.51 & 3.37 & 2.17 & 5.31 & 4.81 & 3.70 & 3.53 & 0.09 & 0.01 & 8.00 \\
\hline $\mathrm{Ta}$ & 0.39 & 0.46 & 0. & 0.10 & 0.20 & 0.26 & 0.14 & 0.10 & 0.10 & 0.37 & $0.3 !$ & 0.10 & 0.17 & 0.10 & 0.10 & 1.28 \\
\hline W & 0.62 & 2.18 & 1.1 & 0.98 & 1.11 & 1.64 & 2.13 & 1.01 & 0.63 & 1.06 & 1.32 & 1.23 & 1.09 & 0.93 & 0.29 & 2.08 \\
\hline $\mathrm{Pb}$ & 5.40 & 3.82 & 3.18 & 3.4 & 3.04 & 3.65 & 4.72 & 4.86 & 4.47 & 6.77 & 5.91 & 3.69 & 4.99 & 1.16 & 1.19 & 12.41 \\
\hline $\mathrm{Th}$ & 0.93 & 0.64 & 0.84 & 0.24 & 0.35 & 0.50 & 0.90 & 0.77 & 0.38 & 4.03 & 2.56 & 1.28 & 2.61 & 0.03 & 0.02 & 20.80 \\
\hline $\mathrm{U}$ & 0.45 & 0.35 & 0.53 & 0.20 & 0.18 & 0.36 & 0.45 & 0.41 & 0.30 & 1.34 & 0.89 & 0.68 & 0.93 & 0.10 & 0.01 & 4.48 \\
\hline $\mathrm{Sr}$ & 212 & 222 & 245 & 160 & 251 & 186 & 358 & 321 & 333 & 287 & 335 & 321 & 399 & 25 & 12 & 87 \\
\hline $\mathrm{Zn}$ & 129 & 132 & 132 & 143 & 117 & 127 & 103 & 108 & 123 & 89 & 76 & 59 & 28 & 48 & 40 & 66 \\
\hline $\mathrm{Ni}$ & 10 & 10 & 56 & 163 & 82 & 69 & 10 & 10 & 10 & 25 & 26 & 42 & 10 & 215 & 183 & 10 \\
\hline Co & 50 & 54 & 66 & 289 & 53 & 45 & 33 & 41 & 49 & 30 & 30 & 30 & 30 & 44 & 35 & 10 \\
\hline $\mathrm{Cr}$ & 30 & 50 & 119 & 289 & 152 & 111 & 33 & 30 & 30 & 41 & 39 & 66 & 30 & 2898 & 3324 & 30 \\
\hline
\end{tabular}

Chemical composition of 13 banded amphibolites (Jiu valley, Km 1 l 8.3), 2 ultramafic rocks (Ml and M2, Micaiai Mt.) and one augen gneiss (AG, F. 26. Râul Bărbat valley from the Drăgsan unit.

Name between brackets are field name of the sample. Rb concentration marked by an asterisk measured by isotope dilution.

best preserved Neoproterozoic orogeny from all the continents, we suggest the use of this term also in Europe in the same way as Caledonian and Variscan names are of worldwide use. We note that these PanAfrican ages in the South Carpathians are in sharp contrast with the adjacent foreland, the basement of the Moesian platform. There, medium- to high-grade metamorphics of Palaeo- to Mesoproterozoic age are unconformably covered by anchimetamorphic turbidites (the 'Green Schists' sequence) of Vendian age (latest Proterozoic; Săndulescu, 1994). The old contaminant involved in the genesis of the dated augen gneiss $\left(T_{\mathrm{DM}}\right.$ 1660-1900 Ma) could be correlated with Moesian but also to other basement such as the 'Altkristallin' from Austria (Thöni and Jagoutz, 1992).

\section{Geochemistry of the Drăgşan metatuffs: an oceanic island arc}

The analysed Drăgşan banded amphibolites from the Jiu valley (Table 3) show a composite trend with three stages in the AFM diagram (Fig. 7A): the first (A) is typically tholeiitic, the second $(B)$ is transitional with calc-alkaline affinities, and the third (C), the most differentiated one, is clearly calc-alkaline. Two ultramafic rocks (pyroxenites) from the Micaia Mount are typical tholeiitic cumulates (samples M1 

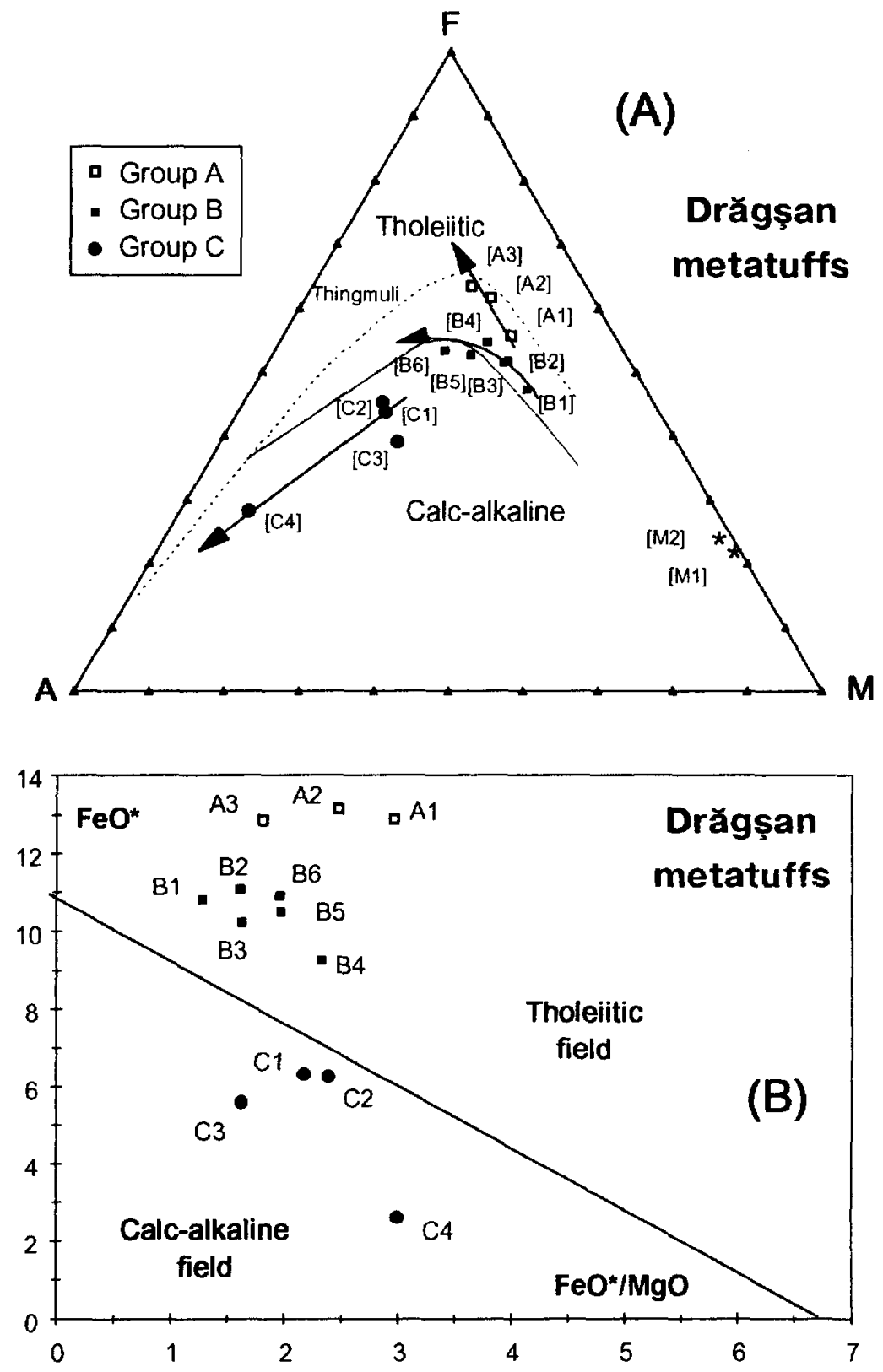

Fig. 7. (A) AFM diagram of the Drăgşan metatuffs $\left(A=\mathrm{K}_{2} \mathrm{O}+\mathrm{Na}_{2} \mathrm{O} ; F=\mathrm{FeO}+0.9 \mathrm{Fe}_{2} \mathrm{O}_{3} ; M=\mathrm{MgO}\right.$ ). The Drăgşan metatuffs define three trends: strongly tholeiitic (group A), mildly tholeiitic (group B) and calc-alkaline (group C). Two ultramafic samples from the Micaia mountain (MI and M2) correspond to tholeiitic cumulates. (B) FeO*/MgO vs. FeO* diagram (Miyashiro, 1974; FeO* is total $\mathrm{Fe}$ expressed as $\mathrm{FeO}$ ) showing the strongly tholeiitic, tholeiitic and calc-alkaline character of $\mathrm{A}, \mathrm{B}, \mathrm{C}$ Drăgşan groups, respectively. Thingmuli dashed line represents a typical tholeiitic trend (Carmichael, 1964).

and $\mathrm{M} 2$ ) in the AFM diagram. This is also shown in the $\mathrm{FeO}^{*} / \mathrm{MgO}$ vs $\mathrm{FeO}^{*}$ diagram (Fig. 7B), with group $\mathrm{A}$ inside the tholeiitic field, group $\mathrm{B}$ nearer to the calc-alkaline field, and group C inside. Group A and $B$ have similar rare earth element distributions (moderately enriched in LREE, $\mathrm{Ce}_{\mathrm{N}} / \mathrm{Yb}_{\mathrm{N}}=2-3$ and 

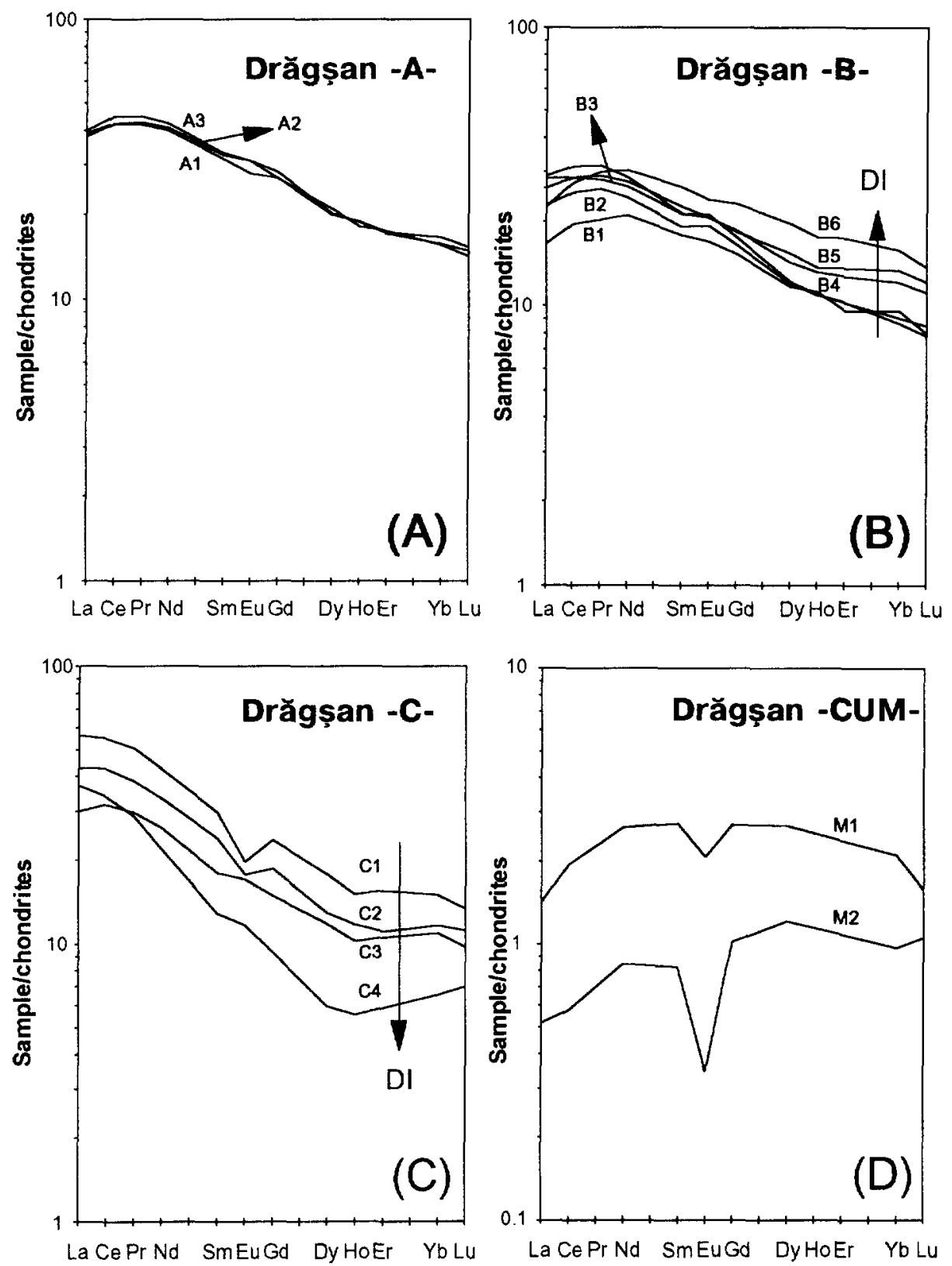

Fig. 8. Chondrite-normalised (Taylor and McLennan, 1985) rare-earth elements diagram of the Drăgşan banded amphibolites: group A (A); group B (B), groups C (C) and Micaia cumulates (D). Sample names ( $A I$ to $A 3 ; B I$ to $B 6 ; C l$ to $C 4$ ) follow the differentiation index of each group defined in the AFM diagram of Fig. 7B. Arrows marked $D I$ show the differentiation trend. Heavy REE have an incompatible behaviour in tholeiitic group $\mathrm{B}$ and a compatible behaviour in calc-alkaline group $\mathrm{C}$.

no Eu anomalies; Figs. 8A and 8B), with higher abundances in group $A$. Inside group $B$, there is an overall REE enrichment from sample $B 1$ to $B 6$ (Fig. 8B). Group $\mathrm{C}$ is more fractionated $\left(\mathrm{Ce}_{\mathrm{N}} / \mathrm{Yb}_{\mathrm{N}}\right.$
$=4-5$; Fig. $8 \mathrm{C}$ ). The least differentiated sample (C1) has a well-marked negative Eu anomaly. This anomaly decreases and disappears through differentiation together with the decrease of the total REE 

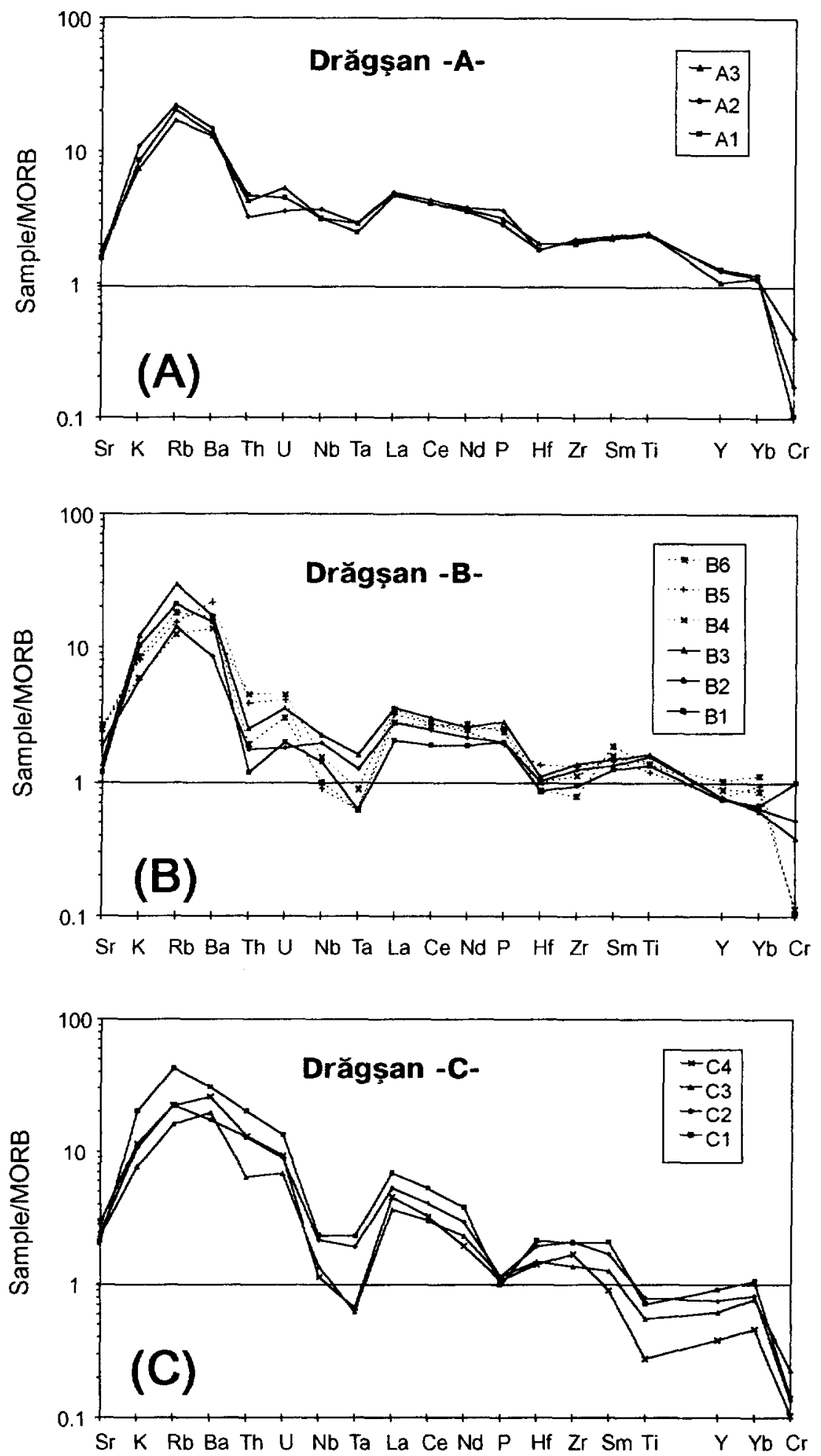

Fig. 9. MORB-normalised diagram (spidergram, Pearce et al., 1981) of the three Drăgşan groups (A, B, C). Tholeiitic group A show a pattern combining oceanic intraplate enriched mantle signature (such as Hawaii) and subduction-related signature. This feature could be met in an oceanic island arc near a back arc basin. The subduction component is larger in groups $B$ and $C$ (see text). 
abundance, suggesting that some accessory minerals rich in REE and with a negative Eu anomaly, such as apatite, has controlled the evolution. The cumulates from Micaia (Fig. 8D, Table 3) have low REE abundances, relatively flat patterns, being slightly depleted in LREE, and show a pronounced Eu negative anomaly. This is in agreement with their pyroxene/ amphibole mineralogy.

MORB normalised spidergrams (Pearce et al., 1981; Pearce, 1982) of group A (Fig. 9A) show a pattern intermediate between an island arc tholeiite (enrichment in $\mathrm{K}, \mathrm{Rb}, \mathrm{Ba}$, slight negative $\mathrm{Nb}-\mathrm{Ta}$ anomaly) and intraplate Hawaii-type basalts ( $\mathrm{Yb}$ around 1 and values increasing regularly from $\mathrm{Yb}$ to $\mathrm{Th}$ ). This suggests a subduction origin involving an enriched mantle. This could be met in a near back-arc environment. Group B has a similar pattern, but with a stronger island arc signature (Fig. 9B) indicating a larger subduction component. Group $\mathrm{C}$ displays strong $\mathrm{Nb}-\mathrm{Ta}$ and $\mathrm{P}$ negative anomalies, is more enriched in LILE, and is comparable to typical calc-alkaline basalts from active margins.

The Ta/Yb vs Th/Yb diagram (Pearce et al., 1984; Fig. 10A) gives a synthetic view: group A (tholeiitic) is close to the primordial mantle (=enriched MORB) with a slight subduction-related component; group B typically falls within the tholeitic oceanic arc field, while group $\mathrm{C}$ lies inside the calc-alkaline oceanic arc field. Oceanic origin and MORB affinity (Savu et al., 1984) of group A amphibolites are also indicated by $\mathrm{Sr}$ and $\mathrm{Nd}$ isotopic initial ratios (Fig. 10B), which plot within the upper end of the mantle array. An oceanic arc origin (back-arc affinity?) without any continental crust component can thus be ascribed to the Drăgşan metatuffs which can be compared to the pre-Variscan island arc of the Tauern window (Vavra and Frisch, 1989).

The dated augen gneiss ( $\mathrm{R} 126,67.7 \% \mathrm{SiO}_{2}$, Table 3 ) differs from the most acidic Drăgşan material $\left(\mathrm{C} 4,66.6 \% \mathrm{SiO}_{2}\right)$ : in Fig. 11A, R126 displays a strong negative $\mathrm{Eu}$ anomaly, higher REE abundance and higher $\mathrm{La}_{N} / Y \mathrm{~b}_{\mathrm{N}}$, when compared to the two extreme terms of group C. Its $\epsilon_{\mathrm{Nd}}$ at $777 \mathrm{Ma}$ is -5.3 indicating a continental crust participation in its genesis, in sharp contrast with the Drăgşan tuffs. On the ocean ridge granite (ORG) normalised spidergram (Pearce et al., 1984), this augen gneiss displays a pattern similar to late-kinematic high-K calc-alkaline Querigut
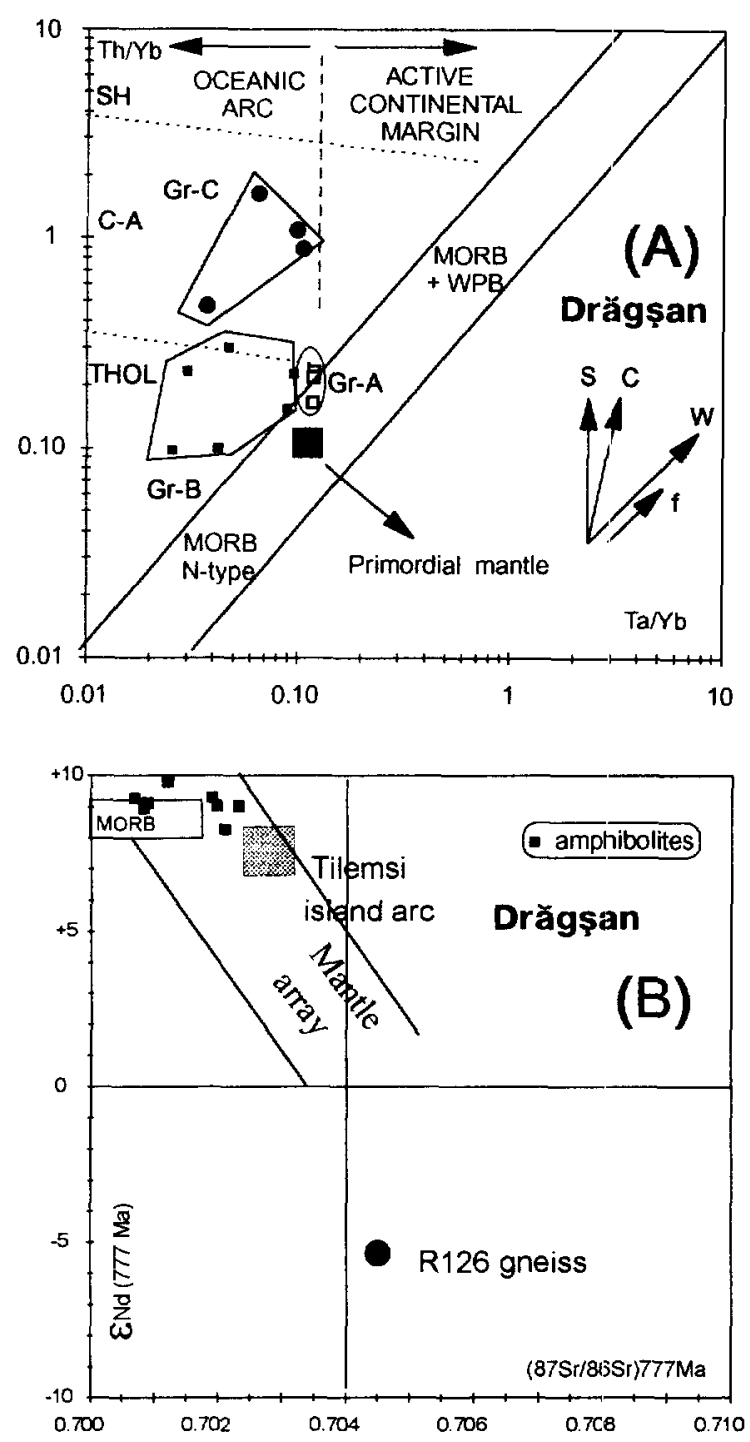

Fig. 10. Oceanic origin of the Drăgşan banded amphibalites. (A) $\mathrm{Ta} / \mathrm{Yb}$ vs $\mathrm{Th} / \mathrm{Yb}$ (Pearce, 1982) showing the enriched MORB affinity of the island arc group $A$ and the evolution to group $B$ and $C$ within the oceanic island arc field. The arrows represent the effect of a subduction component $[S]$, crustal contamination $[C]$, within-plate component $[W]$ and fractional crystallization $[f]$. (B) Initial $\mathrm{Sr}$ and $\mathrm{Nd}$ (expressed as $\epsilon_{\mathrm{Nd}}$ ) ratios calculated at 777 Ma. The Drăgşan banded amphibolites possess a strong mantle signature excluding any old crust participation in contrast to the R 126 augen gneiss protolith. For the latter, only the $\epsilon_{\mathrm{Nd}}$ has been calculated at $777 \mathrm{Ma}$. The $\mathrm{Sr}$ initial ratio has been estimated due to $\mathrm{Rb}-\mathrm{Sr}$ isotopic system resetting probably diring Variscan times (Fig. 5B). Tilemsi is a $730 \mathrm{Ma}$ old oceanic island arc from the western Tuareg shield (Liégeois, 1988; Caby et al., 1989; Fig. 6). 

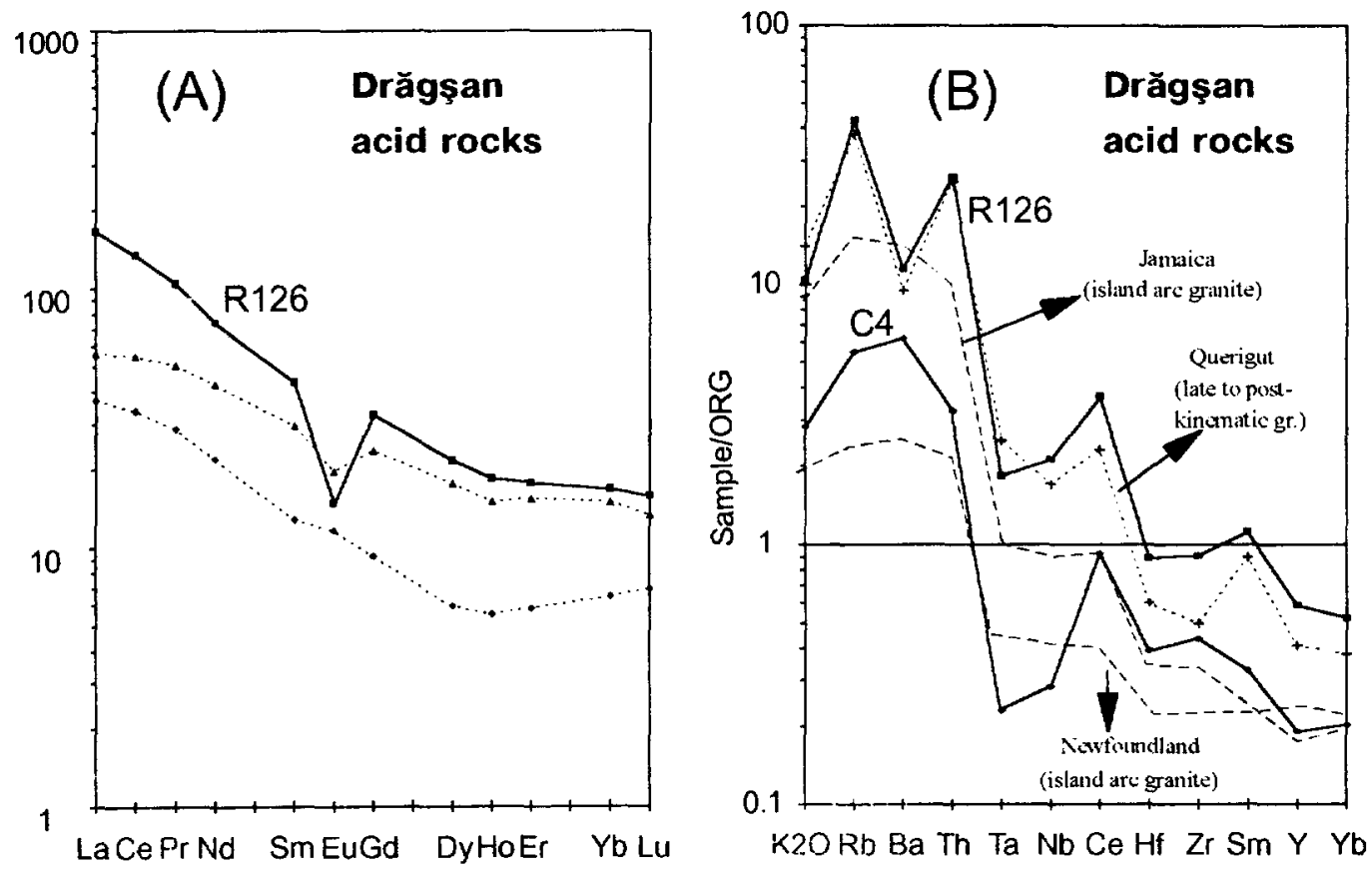

Fig. 11. The nature of the acid rocks from the Drăgşan unit. (A) Chondrite-normalised REE diagram showing the difference between the calc-alkaline acid rocks of group $C$ and the R126 augen gneiss. (B) Ocean ridge granite (ORG)-normalised spidergram (Pearce et al., 1984). Group $C$ differentiates are in the range of oceanic island arc granites (Newfoundland and Jamaica) while $R 126$ augen gneiss protolith is similar to the French Variscan late-kinematic calc-alkaline Querigut granite.

granite (Fig. 11B). In the Pan-African Tuareg shield, this kind of spectrum is typical of the late- to postkinematic granites, which also show slightly negative $\epsilon_{\mathrm{Nd}}$. In contrast, the $\mathrm{C} 4$ acid metatuff (R122) associated with the basic metatuffs and which has an oceanic isotopic signature (at $777 \mathrm{Ma}, \epsilon_{\mathrm{Nd}}=+9.2$ ), shows a pattern comparable to island arc granites (Pearce et al., 1984). We can thus suggest that the augen gneiss protolith probably intruded after the accretion of the Drăgşan island arc with a continent. The problem of whether this continent was represented by the Lainici-Păiuş Group or not cannot be solved at present. Subsequently to the amphibolite facies metamorphism affecting the Drăgşan Group, several large granitoid plutons, not studied here, intruded in one or several pre-Variscan phases.

\section{Preliminary geochemical results on the dated Tismana pluton}

The Tismana massif comprises two petrographical types (Berza, 1978): porphyritic monzogranites with
$\mathrm{K}$-feldspar megacrysts up to $10 \mathrm{~cm}$ and equigranular diorites and quartz diorites. Intermediate granodioritic rocks, interpreted as resulting from a mingling/mixing process, are also present. Tismana displays an alkali-calcic trend in a Peacock diagram (Brown, 1961), with the intersection near the alkaline field (Fig. 12A). Potash content increases from $2 \%$ to $4 \%$ in the $48-52 \% \mathrm{SiO}_{2}$ range and from $4 \%$ to $6 \%$ in the 52 to $70 \% \mathrm{SiO}_{2}$ range (Fig. 12B). The slight increase of $\mathrm{K}_{2} \mathrm{O}$ from $52 \% \mathrm{SiO}_{2}$ upwards reflects a higher increase of $\mathrm{K}$-feldspar relative to a concomitant decrease of biotite (Berza, 1978). The Tismana trend lies entirely within the shoshonitic or alkaline field (Fig. 12B). In the $\mathrm{Zr}+\mathrm{Nb}+\mathrm{Ce}+\mathrm{Y}$ vs $\mathrm{K}_{2} \mathrm{O}+$ $\mathrm{Na}_{2} \mathrm{O} / \mathrm{CaO}$ diagram (Whalen et al., 1987; Fig. 12C), Tismana has A-type affinities, shown only by trace elements due to relatively low $\mathrm{Na}_{2} \mathrm{O}$ abundances (2$3 \%$ for the whole silica range; agpaitic index $<0.8$ ). This points to a very high- $\mathrm{K}$ calc-alkaline character $\left(\mathrm{K}_{2} \mathrm{O} / \mathrm{Na}_{2} \mathrm{O}\right.$ ratio up to 2$)$ for the massif. A detailed geochemical study on Tismana, showing that the genesis of this massif has been greatly controlled by frac- 
tional crystallization and mixing processes leading to a composite series (following Rossi and Cocherie, 1991), will be published elsewhere (Duchesne et al., in prep.).

\section{Conclusions}

(1) Both basements present in the Danubian of the South Carpathians are Late Precambrian in age.

(2) The protolith of an augen gneiss from the Drăgşan basement has been dated at $777 \pm 3 \mathrm{Ma}$ ( $\mathrm{U}-\mathrm{Pb}$ zircon). This age is a minimum age but is close to the age of amphibolite protoliths ( $T_{\mathrm{DM}}$ model ages of maximum $820 \mathrm{Ma}$ ). The ages of the regional amphibolite facies metamorphism and lateto post-kinematic granitoids are not precisely known.

(3) The ages of the various syn- to late-kinematic granitoid intrusives in the Lainici-Păiuş basement are in the 588-567 Ma range. The regional LP-HT metamorphism is probably not much older.

(4) The major and trace elements, together with $\mathrm{Sr}$ and $\mathrm{Nd}$ isotopes indicate that the Drăgşan banded amphibolites represent an oceanic island arc with no participation of older continental crust. These metatuffs display a composite trend with an evolution from tholeiitic to low-K calc-alkaline, showing probable interaction between island arc and back-arc environments. Late accretion of these oceanic rocks on a continent is marked by late-kinematic high$\mathrm{K}$ calc-alkaline granitoids, in the genesis of which continental crust participated. This event was followed by an amphibolite facies metamorphism and by a second generation of late to post-kinematic leucogranitoids.

(5) Preliminary geochemical data on one of the plutons that intrude the Lainici-Păiuş basement indicate a very high-K calc-alkaline trend (alkali-calcic).

Fig. 12. Preliminary geochemical characteristıcs of the $\sim 567 \mathrm{Ma}$ old Tismana granitoids (intrusive in the Vâlcan-Pilugu thrust unit). (A) $\mathrm{SiO}_{2}$ vs $\mathrm{CaO} / \mathrm{Na}_{2} \mathrm{O}+\mathrm{K}_{2} \mathrm{O}$ diagram (Peacock index following Brown, 1961). $A=$ alkalic, $A-C=$ alkali-calcic, $C$ $A=$ calc-alkalic, and $C=$ calcic. An alkali-calcic to alkalic signature is defined. (B) $\mathrm{SiO}_{2}$ vs $\mathrm{K}_{2} \mathrm{O}$ diagram showing the highly potassic character of the Tismana pluton. (C) $\mathrm{Zr}+\mathrm{Nb}+$ $\mathrm{Ce}+\mathrm{Y}$ vs $\mathrm{Na}_{2} \mathrm{O}+\mathrm{K}_{2} \mathrm{O} / \mathrm{CaO}$ diagram. If total alkali content is quite normal, high HFS element abundance points to an A-type affinity of the Tismana pluton. This is linked to its very high-K calc-alkaline character.
(6) The Pan-African orogeny in northern Africa (Fig. 6) with its two coupled phases (early phase 800-650 Ma, late phase 640-550 Ma; Liégeois et al.,
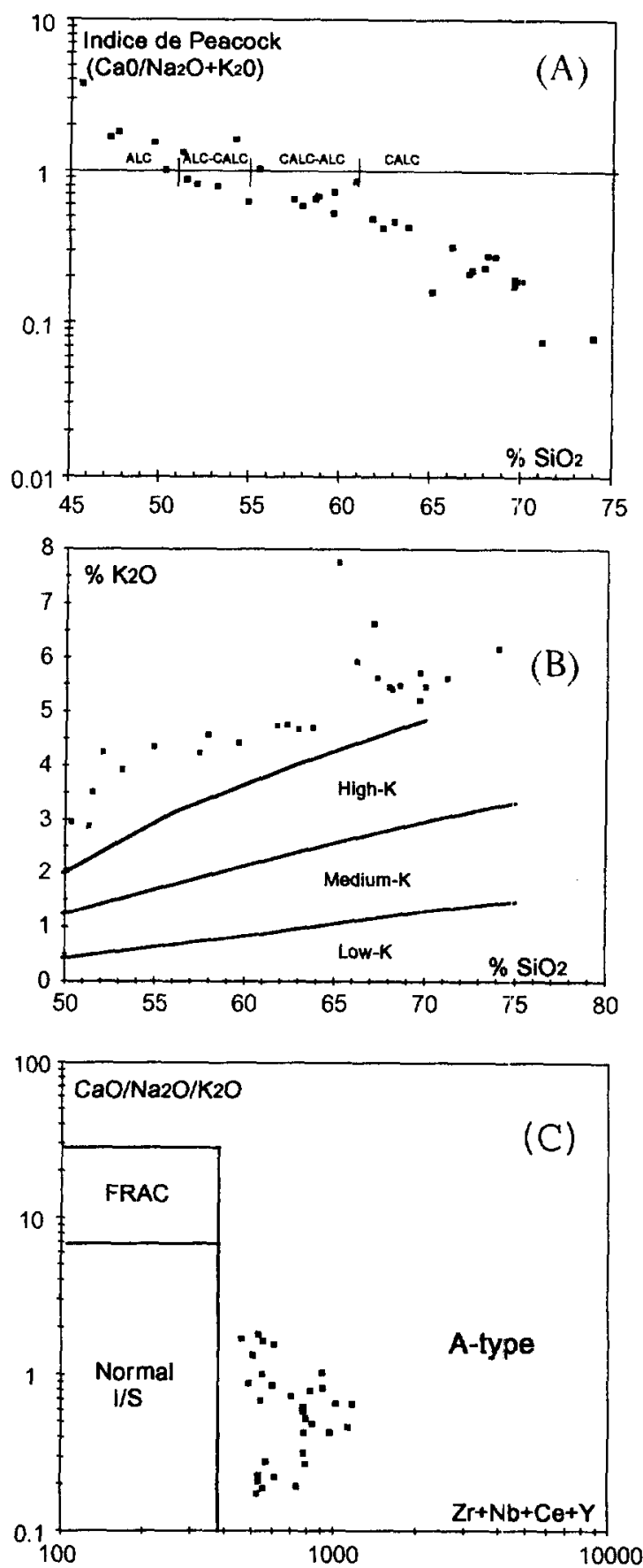
1994), abundance of early juvenile oceanic terranes and of late high-K calc-alkaline to alkaline granitoids, polybar high-grade metamorphism and great relative mobility of terranes (Black et al., 1994), represents an important correlative.

\section{Acknowledgements}

G. Bologne, G. Delhaze (ULG) and C. Gilson (MRAC) are greatly thanked for their help in chemical analyses and mineral separations. Isotopic data have been performed within the framework of the Belgian Centre for Geochronology (MRAC-ULB). Major and some trace elements were analysed at the "Collectif interinstitutionnel de Géochimie instrumentale' (Dir. J.C. Duchesne). Most of the trace elements were analyzed at the MRAC under the supervision of J. Navez. The authors have benefited from a NATO CR 920516 grant and the Geological Institute of Romania has provided logistic support for the field work. R. Black is thanked for having checked the English. The paper has benefited from the careful reviews of F. Neubauer, D. Bridgwater and of an anonymous reviewer.

\section{Appendix A. Analytical techniques}

Isotopic measurements have been carried out on a Fisons VG Sector 54 and on a Finnigan MAT 260 mass spectrometer.

\section{A.I. $R b-S r, S m-N d$}

After acid digestion in Teflon bombs of the sample and Sr or $\mathrm{Nd}$ separation on ion-exchange resin, $\mathrm{Sr}$ isotopic compositions have been measured on Ta simple filament and $\mathrm{Nd}$ isotopic compositions on triple Ta-Re-Ta filament. Repeated measurements of $\mathrm{Sr}$ and $\mathrm{Nd}$ standards have shown that between-run error is better than 0.00002 . This error has been chosen in the calculations in the general cases where the within-run errors are lower. The NBS987 standard has given a value for ${ }^{87} \mathrm{Sr} /{ }^{86} \mathrm{Sr}$ of 0.710258 \pm 0.000005 during this study ( $2 \sigma$ on the mean, normalised to $\left.{ }^{86} \mathrm{Sr} /{ }^{88} \mathrm{Sr}=0.1194\right)$ and the MERCK Nd standard a value for ${ }^{143} \mathrm{Nd} /{ }^{144} \mathrm{Nd}$ of $0.512740 \pm 0.000005$ ( $2 \sigma$ on the mean, normalised to ${ }^{146} \mathrm{Nd} / 144 \mathrm{Nd}=0.7219$ ). $\mathrm{Rb}$ and $\mathrm{Sr}$ concentrations have been measured by $\mathrm{X}$-ray fluorescence or by isotope dilution when concentrations were $<30 \mathrm{ppm}$. The error on the $\mathrm{Rb} / \mathrm{Sr}$ ratio is $<2 \%$. Sm and $\mathrm{Nd}$ concentrations were measured by ICP-MS. The error on the $\mathrm{Sm} / \mathrm{Nd}$ ratio is $<2 \%$. The $\mathrm{Rb}-\mathrm{Sr}$ and $\mathrm{Sm}-\mathrm{Nd}$ ages have been calculated following Ludwig (1995) and all the errors are given at the $2 \sigma$ level. Used decay constants are 1.42 $\times 10^{-11} \mathrm{a}^{-1}\left({ }^{87} \mathrm{Rb}\right.$, Steiger and Jäger, 1977) and $6.5410^{-12} \mathrm{a}^{-1}$ $\left({ }^{147} \mathrm{Sm}\right)$.

\section{A.2. $U-P b$}

The method is derived from that of Krogh (1973) and Lancelot (1975). About five zircon crystals (few inclusions, crack-free) were chosen. $\mathrm{Pb}$ was separated on ion exchange resin after acid dissolution. $\mathrm{Pb}$ is measured on single rhenium single filament and $U$ on triple Ta-Re-Ta triple filament, both with silica gel. The fractionation factor is equal to $0.12 \%( \pm 0.1 \%)$ per a.m.u. Disintegration constants: ${ }^{235} \mathrm{U}=9.8485 \times 10^{-10}$ $\mathrm{a}^{-1} ;{ }^{238} \mathrm{U}=1.55125 \times 10^{-10} \mathrm{a}^{-1}$ (Steiger and Jäger, 1977). The intercepts with concordia and errors have been calculated following Ludwig (1980). For details, see Liégeois et al. (1991).

\section{A.3. Major elements}

$\mathrm{XRF}$ on Li borate and carbonate (with La) glass discs was used to determine major elements except $\mathrm{Na}$ which was measured on pressed raw material; $\mathrm{FeO}$ has been determined by titration (Bologne and Duchesne, 1991).

\section{A.4. Trace elements}

Three different techniques have been used for the analysis of 29 trace elements: $\mathrm{X}$-ray fluorescence on raw material for $\mathrm{Rb}$ and $\mathrm{Sr}$; ICP-AES for $\mathrm{Cu}, \mathrm{Zn}, \mathrm{Cr}$ and $\mathrm{Co}$ (for details, see Navez, 1983); ICP-MS for all the other elements. The result of the alkaline digestion $(0.3 \mathrm{~g}$ of sample $+0.9 \mathrm{~g}$ of lithium metaborate at $1000^{\circ} \mathrm{C}$ during one hour) has been dissolved in $\mathrm{HNO}_{3} 5 \%$. The calibration curves were established with both artificial and international rock standards. For all these elements, the precision varies from 5 to $10 \%$ (for details, see Navez, 1995).

\section{References}

Berza, T., 1978. Studiul mineralogic şi petrografic al masivului granitoid de Tismana. An. Inst. Geol. Geof., LIII: 5-176.

Berza, T. and Drăgănescu, A., 1988. The Cerna-Jiu fault system (South Carpathians, Romania), a major Tertiary transcurrent lineament. D. S. Inst. Geol. Geof., 72-73/5: 43-47.

Berza, T. and Iancu, V., 1994. Variscan events in the basement of the Danubian nappes (South Carpathians). Rom. J. Tect. Reg. Geol., 75, Suppl. 2 (Alcapa II): 93-103.

Berza, T. and Seghedi, A., 1975. Complexul filonian presilurian din bazinul Motrului (Carpaţii Meridionali). D. S. Inst. Geol. Geof., LXI/1: 131-149.

Berza, T. and Seghedi, A., 1983. The crystalline basement of the Danubian units in the Central South Carpathians. An. Inst. Geol. Geof., LXI: 15-22.

Berza, T., Kräutner, H. and Dimitrescu, R., 1983. Nappe structure in the Danubian window of the Central South Carpathians. An. Inst. Geol. Geof., LX: 31-38.

Berza, T., Balintoni, I., Iancu, V., Seghedi, A. and Hann, H.P., 1994. South Carpathians. Rom. J. Tect. Reg. Geol., 75, Suppl. 2 (Alcapa II): 37-50.

Black, R. and Liégeois, J.P., 1993. Cratons, mobile belts, alkaline rocks and continental lithospheric mantle: the Pan-African testimony. J. Geol. Soc. London, 150: 89-98. 
Black, R., Latouche, L., Liégeois, J.P., Caby, R. and Bertrand, J.M., 1994. Pan-African displaced terranes in the Tuareg shield (central Sahara). Geology, 22: 641-644.

Bologne, G. and Duchesne, J.C., 1991. Analyse des roches silicatées par spectrométrie de fluorescence $\mathrm{X}$ : précision et exactitude. Serv. Géol. Belg. Prof. Pap., 249: 1-11.

Brown, G.C., 1961. Space and time in plutonism. Phil. Trans. R. Soc. London, A301: 321-336.

Caby, R. and Andreopoulos-Renaud, U., 1987. Le Hoggar oriental, bloc cratonisé à $730 \mathrm{Ma}$ dans la chaîne Pan-Africaine du nord du continent africain. Precambrian Res., 36: 335-344.

Caby, R., Andreopoulos-Renaud, U. and Gravelle, M., 1982. Cadre géologique et géochronologie $\mathrm{U} / \mathrm{Pb}$ sur zircon des batholites précoces dans le segment Pan-Africain du Hoggar central (Algérie). Bull. Soc. Géol. Fr., 24: 677-684.

Caby, R., Andreopoulos-Renaud, U. and Pin, C., 1989. Late Proterozoic arc-continent and continent-continent collision in the Pan-African Trans-Saharan belt of Mali. Can. J. Earth Sci, 26: 1136-1146.

Carmichael, I.S.E., 1964. The petrology of Thingmuli, a Tertiary volcano in eastern Iceland. J. Petrol., 5: 435-460.

Choubert, G., Faure-Muret, A., Chanteux, P., Luettig, G. and Zhamoida, A.I., 1984. Atlas Géologique du Monde au 1/10000000, feuille 9, C.G.M.W., Unesco.

Codarcea, A., 1940. Vues nouvelles sur la tectonique du Banat et du Plateau de Mehedinti. An. Inst. Geol. Geof., XX: 1-74.

Codarcea, A., Lupu, M., Codarcea-Dessila, M. and Lupu, D., 1967. Unitatea supragetică în Carpaţii Meridionali. St. Cerc. Deol. Geof. Geogr., Geol., 12/2: 387-392.

Dallmeyer, R.D. and Neubauer, F., 1994. Cadomian 40Ar/39Ar apparent age spectra of detrital muscovites from the Eastern Alps. J. Geol. Soc. London, 151: 591-598.

Dallmeyer, R.D., Neubauer, F., Mocanu, V. and Fritz, H., 1994a. ${ }^{40} \mathrm{Ar} /{ }^{39} \mathrm{Ar}$ mineral age controls for the pre-Alpine and Alpine tectonic evolution of nappe complexes in the Southern Carpathians. Rom. J. Tect. Reg. Geol., 75, Suppl. 2 (Alcapa II), 77-86.

Dallmeyer, R.D., Neubauer, F., Fritz, H. and Mocanu, V., 1994b. Pre-Variscan, Variscan and Alpine tectonothermal evolution within the Southern Carpathians, Romania: evidence from ${ }^{40} \mathrm{Ar} /{ }^{39} \mathrm{Ar}$ hornblende and muscovite ages. Rom. J. Tect. Reg. Geol., 75, Suppl. 1 (Alcapa II), 10-12.

Duchesne, J.C., Berza, T., Liégeois, J.P. and Vander Auwera, J., in prep. A very high-K calc-alkaline suite, the Late Precambrian Tismana pluton (South Carpathians, Romania): mantle source and crustal differentiation/assimilation.

Finger, F., Frasl, G., Höck, V. and Steyrer, H.P., 1989. The granitoids of the Moravian zone of Northeast Austria: products of a Cadomian active continental margin? Precambrian Res., 45: 235-245.

Golstein, S.L., O’Nions, R.K. and Hamilton, P.J., 1984. A Sr-Nd isotopic study of atmospheric dots and particulates from major river systems. Earth Planet. Sci. Lett., 70: 221-236.

Grünenfelder, M., Popescu, G., Soroiu, M., Arsenescu, V. and Berza, T., 1983. K-Ar dating of metamorphic and associated rocks in the Central South Carpathians. An. Inst. Geol. Geof., LXI: $31-38$.
Kräutner, H.G., 1988. Precambrian in the Carpathians. Introduction. In: V. Zoubek (Editor), Precambrian in Younger Fold Belts. J. Wiley, London, pp. 621-623.

Kräutner, H.G., 1993. Pre-Alpine evolution in the Southern Carpathians and adjacent areas. Geol. Carpathica, 44, 4: 203 212.

Kräutner, H.G., 1994. Pre-Alpine terranes in the Romanian Carpathians. Rom. J. Tect. Reg. Geol., 75, Suppl. 1 (Alcapa II): $31-32$

Kräutner, H.G., Năstăseanu, S., Berza, T., Stănoiu, I. and Iancu, V., 1981. Metamorphosed Paleozoic in the South Carpathians and its relation with the pre-Paleozoic basement. Guide to Excursion A, Carp. Balk. Geol. Assoc. Congr. XII, Bucuresţi, $116 \mathrm{pp}$.

Kräutner, H.G., Berza, T. and Dimitrescu, R., 1988. South Carpathians. In: V. Zoubek (Editor), Precambrian in Younger Fold Belts. J. Wiley, London, pp. 633-664.

Krogh, T.R., 1973. A low contamination method for hydrothermal decomposition of zircon and extraction of $\mathrm{U}$ and $\mathrm{Pb}$ for isotopic age determination. Geochim. Cosmochim. Acta, 37: 485-494.

Kröner, A., Hegner, E., Hammer, J., Haase, G., B.ielicki, K.H., Krauss, M. and Eidam, J., 1994. Geochronology and NdSr systematics of Lusatian granitoids: significance for the evolution of the Variscan orogen in east-central Europe. Geol. Rundsch., 83: 357-376.

Lancelot, J.R., 1975. Les systèmes U-Pb chronomètres et traceurs de l'évolution des roches terrestres. Ph.D. dissertation, University of Paris VII, $280 \mathrm{pp}$.

Liégeois, J.P., 1988. Le batholite composite de l'Aclrar des Iforas (Mali). Acad. R. Sci. Outre-Mer, Classe Sci. Nat. Méd., Bruxelles, Mém., 8, 22, 231 pp.

Liêgeois, J.P., Bertrand. J.M. and Black, R.. 1987. The subduction- and collision-related Pan-African composite batholith of the Adrar des Iforas (Mali): a review. Geol. J., 22: $185-211$

Liégeois, J.P., Claessens, W., Camara, D. and Klerkx, J., 1991. Short-lived Eburnian orogeny in southern Mali. Geology, tectonics, $\mathrm{U}-\mathrm{Pb}$ and $\mathrm{Rb}-\mathrm{Sr}$ geochronology. Precambrian Res., 50: 111-136.

Liégeois, J.P., Black, R., Navez, J. and Latouche, L., 1994. Early and late Pan-African orogenies in the Aïr assembly of terranes (Tuareg shield, Niger). Precambrian Res., 67: 59-88.

Ludwig, K.R., 1980. Calculation of uncertainties of U-Pb isotope date. Earth Planet. Sci. Lett., 46: 212-220.

Ludwig, K.R., 1995. Isoplot, a plotting and regression program for radiogenic-isotope data (ver. 2.82). Revision of the U.S. Geological Survey Open File Report, 91-445, 45 pp.

Manolescu, G., 1937. Etude géologique et pétrographique dans les Munţii Vulcan (Carpathes méridionales, Roumanie). An. Inst. Geol. Rom., XVIII: 79-172.

Michard, A., Gurriet, P., Soudant, M. and Albarède, F., 1985. Nd isotopes in French Phanerozoic shales: external vs internal aspects of crustal evolution. Geochim. Cosmochim. Acta, 49: $601-610$.

Mînzatu, S., Lemne, M., Vîjdea, E., Tănăsescu, A., Ioncică, M. and Tiepac, I., 1975. Date geocronologice cbținute pentru 
formaţiuni cristalofiliene şi masive eruptive din România. D.S. Inst. Geol. Geof., LXV/5: 85-100.

Miyashiro, A., 1974. Volcanic rocks series in island arcs and active continental margins. Am. J. Sci., 274: 321-355.

Murgoci, G.M., 1905. Sur l'existence d'une grande nappe de recouvrement dans les Karpathes méridionales. C.R. Acad. Sci. Paris, 31 juillet 1905.

Navez, J., 1983. Détermination de 11 éléments en traces dans les roches silicatées par spectrométrie d'émission dans un plasma à couplage inductif. Rapp. Annu. Dépt. Géol. Min. 19811982, Musée Royal Afrique Centrale, Tervuren, pp. 115-118.

Navez, J., 1995. Détermination d'éléments en traces dans les roches silicatées par ICP-MS. Rapp. Annu. Dépt. Géol. Min. 1993-1994, Musée Royal Afrique Centrale. Tervuren, in press.

Nelson, B.K. and De Paolo, D.J., 1985. Rapid production of continental crust 1.7 to 1.9 b.y. ago: $\mathrm{Nd}$ isotopic evidence from the basement of the North American mid-continent. Geol. Soc. Am. Bull., 96: 746-754.

Neubauer, F., 1991. Late Proterozoic and early Paleozoic tectonothermal evolution of the eastern Alps. In: R.D. Dallmeyer and J.P. Lécorché (Editors), The West African Orogens and Circum-Atlantic Correlatives. Springer Verlag, Berlin, pp. 307-314.

Pavelescu, L., 1953. Studiul geologic şi petrografic al regiunii centrale şi de Sud-Est al Munţilor Retezatului. An. Com. Geol., XXV: 119-210.

Pearce, J.A., 1982. Role of the sub-continental lithosphere in magma genesis at active continental margins. In: C.J. Hawkesworth and M.J. Norry (Editors), Continental Basalts and Mantle Xenoliths. Shiva Geology Series, Nantwich, pp. 230-249.

Pearce, J.A., Alabaster, T., Shelton, A.W. and Searle, M.P., 1981. The Oman ophiolite as a Cretaceous arc-basin complex: evidence and implications. Philos. Trans. R. Soc. London, A300: 299-317.

Pearce, J.A., Harris, N.B.W. and Tindle, A.G., 1984. Trace element discrimination diagrams for the tectonic interpretation of granitic rocks. J. Petrol., 25: 956-983.

Pin, C., 1991. Central-Western Europe: major stages of development during Precambrian and Paleozoic times. In: R.D. Dallmeyer and J. Lécorché (Editors), The West African Orogens and Circum-Atlantic Correlatives. Springer Verlag, Berlin, pp. 295-306.

Ratschbacher, L., Liuzer, H.G., Moser, F., Strusieavicz, R.O., Bedelean, H., Har, N. and Mogoş, P.A., 1993. Cretaceous to Miocene thrusting and wrenching along the Central South Carpathians due to a corner effect during collision and orocline formation. Tectonics, 12, 4: 855-873.

Raumer, J.F. von and Neubauer, F., 1993. Late Precambrian and Palaeozoic evolution of the Alpine basement-an overview. In: J.F. von Raumer and F. Neubauer (Editors), Pre-Mesozoic Geology in the Alps. Springer-Verlag, Berlin, pp. 625-639.

Rossi, P. and Cocherie, A., 1991. Genesis of a Variscan batholith. Field, petrological and mineralogical evidence from the Corsica-Sardinia batholith. In: R. Freeman, M. Huch and S. Mueller (Editors), The European Geotraverse. Tectonophysics, 195: 319-346.

Săndulescu, M., 1994. Overview on Romanian geology. Rom. J. Tect. Reg. Geol., 75, Suppl. 2: 3-16.

Savu, H., 1970. Structura plutonului granitoid de Suşiţa şi relaţii le sale cu formaţiunile autochtonului danubian (Carpaţii Meridionali). D. S. Inst. Geol., LVI/5: 125-153.

Savu, H., Vasiliu, C. and Udrescu, C., 1971. Studiul petrologic şi geochimic al granitoidelor sinorogene şi tardeorogene din zona plutonului de Suşiţa (Carpaţii Meridionali). An. Inst. Geol., XXXIX: 257-297.

Savu, H., Bratosin, I. and Neacşu, V., 1984. Remarks on the petrology, geochemistry and tectonics of the geological formations of the Paring Mountains concerning especially the Drăgşan amphibolite series (South Carpathians). D. S. Inst. Geol. Geofiz., 72-73/1: 361-379.

Schandelmeier, H., Utke, A., Harms, U. and Küster, D., 1990. A review of the Pan-African evolution of NE Africa: towards a new dynamic concept for continental NE Africa. Berl. Geowiss. Abh., A120: 1-14.

Schuster, A.C., 1980. Geologische und petrographische Unterschungen im Danubikum der Süd Karpaten, ParîngGebirge, Rumänien. Ph.D. dissertation, Technische Universität Clausthal, $178 \mathrm{pp}$.

Stacey, J.S. and Kramers, J.D., 1975. Approximation of terrestrial lead isotope evolution by a two-stage model. Earth Planet. Sci. Lett., 26: 207-221.

Stănoiu, I., 1973. Zona Mehedinţi-Retezat, o unitate paleogeografică şi tectonică distinctă a Carpaţilor Meridionali. D. S. Inst. Geol., LIX/5: 127-171.

Steiger, R.H. and Jäger, E., 1977. Subcommission on geochronology: convention on the use of decay constants in geo- and cosmochronology. Earth Planet. Sci. Lett., 36: 359-362.

Stille, P. and Tatsumoto, M., 1985. Precambrian tholeiitic-dacitic rock-suites and Cambrian ultramafic rocks in the Penninic nappe system of the Alps: evidence from Sm-Nd isotopes and rare earth elements. Contrib. Mineral. Petrol., 89: 184-192.

Streckeisen, A., 1934. Sur la tectonique des Carpathes méridionales. An. Inst. Geol., XVI: 327-481.

Taylor, S.R. and McLennan, S.M., 1985. The Continental Crust: Its Composition and Evolution. Blackwell, Oxford.

Thöni, M. and Jagoutz, E., 1992. Some new aspects of dating eclogites in orogenic belts: $\mathrm{Sm}-\mathrm{Nd}, \mathrm{Rb}-\mathrm{Sr}$ and $\mathrm{Pb}-\mathrm{Pb}$ isotopic results from the Austroalpine Saualpe and Koralpe typelocality (Carinthia/Styria, southeastern Austria). Geochim. Cosmochim. Acta, 56: 347-368.

Vavra, G. and Frisch, W., 1989. Pre-Variscan back-arc and island arc magmatism in the Tauern window (Eastern Alps). Tectonophysics, 169: 271-280.

Whalen, J.B., Currie, K.L. and Chapell, B.W., 1987. A-type granites: geochemical characteristics, discrimination and petrogenesis. Contrib. Mineral. Petrol., 95: 407-419. 